\title{
Basement-involved thin-skinned and thick-skinned tectonics in the Alps
}

\author{
O. ADRIAN PFIFFNER* \\ Institute of Geological Sciences, University of Bern, Baltzerstrasse 1+3, CH-3012 Bern, Switzerland
}

(Received 9 August 2015; accepted 6 December 2015; first published online 22 January 2016)

\begin{abstract}
The deformation of continental crust during continental collision by folding and thrusting follows three types of structural styles: (1) in a true thin-skinned style only cover rocks are involved; (2) in the case of a thin-skinned basement-involved style, thin slabs of crystalline basement rocks are piled up into a nappe stack; (3) in a true thick-skinned style, the entire upper crust is involved in the deformation. In the Alps all three styles can be recognized. The Helvetic nappes and parts of the Penninic nappes exhibit true thin-skinned style tectonics. Triassic evaporites, Jurassic shales and Cretaceous marls acted as detachment horizons. Basement-involved thin-skinned tectonics is typical for the Penninic nappes in the core of the orogen. The thickness of the basement thrust sheets is controlled by the effects of Mesozoic rifting, by deep burial and heating of the subducting crust and by the presence of Late Palaeozoic structures. Thick-skinned style is observed in the more external parts of the orogen, the external massifs and the Southalpine nappe system. It occurred in the late phase of collision and involved the entire upper crust. The basal detachment occurred possibly along phyllonites generated by the breakdown of load-bearing feldspar. Considering the Alpine orogen as a whole, the lower crust deformed seemingly independently from the upper crust. The detachment of the cover units by thin-skinned tectonics occurred prior to thrusting related to basement-involved thin-skinned tectonics. Thrust faults of both types were overprinted by 'post-nappe folding'.
\end{abstract}

Keywords: nappe formation, Alpine tectonics, Penninic nappes, Helvetic nappes, crustal structure, tectonic evolution, basement nappes.

\section{Introduction}

Faults and folds are essential parts of any mountain belt and determine the style of the deep structure of the orogen. In addition the distinction between crystalline basement rocks and sedimentary strata are key features to further characterize this style. As early as 1949 Rodgers used the presence of crystalline rocks in the Appalachians to make a distinction between thick-skinned and thin-skinned tectonics (Rodgers, 1949). Hereby, thin-skinned tectonics implies that thrust sheets are made of sedimentary strata only, whereas in thick-skinned tectonics crystalline basement is involved in thrusting as well. If collision orogens are considered it emerges quickly that basement involvement may occur in different settings. Relatively thin thrust sheets made up of mainly crystalline rocks are piled up in the core of the Alpine orogen (e.g. Heim, 1919-22), the Caledonides of Scotland (Elliott \& Johnson, 1980) or Scandinavia (Heim, Schärer \& Milnes, 1977). On the other hand, thrust faults affecting the entire crust have been reported from the foreland of the North American and Andean cordilleras (e.g. Smithson et al. 1978) or the Alice Springs orogen in Australia (Teyssier, 1985). These examples correspond to truly thick-skinned tectonics. To better distinguish these cases it is suggested to restrict the term thick-

*Author for correspondence: adrian.pfiffner@geo.unibe.ch skinned tectonics to the cases where the entire crust is involved, and use the term basement-involved thinskinned tectonics for the cases where thrust sheets are made of upper crustal flakes only (Pfiffner, 2006).

In thin-skinned tectonics sedimentary strata are detached from their basement along a decollement horizon made up of rocks with low shear strength. Typical examples include evaporites (salt or anhydrite) and shales. In most cases there are several thrust faults (or thrust sheets) involved with thin-skinned tectonics. While the thrust faults sole into the decollement horizon, they climb up section in the direction of transport forming ramps across mechanically strong layers such as, for example, carbonates.

The Sevier fold-and-thrust belt in Wyoming shown in Figure $1 \mathrm{a}$ is a classic example of thin-skinned tectonics. Decollement horizons are present in Neoproterozoic micaceous rocks (Paris and Meade thrusts), Cambrian shales for all of the thrust faults and Triassic evaporites (Prospect thrust; Royse, 1993). Thrusting can be dated based on Cenozoic synorogenic clastic rocks (Royse, 1993; DeCelles, 1994, 2004; Yonkee \& Weil, 2015). According to these authors, thrusting migrated from west to east: the Paris thrust in Early Cretaceous time, the Meade and Crawford in Late Cretaceous time, the Absaroka and Darby in Late Cretaceous to Paleocene times and the Prospect thrust in mid Paleocene to Early Eocene times. Estimates for displacements along individual thrust faults are taken from Royse (1993). The 


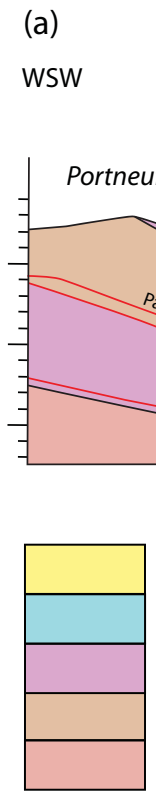

(a)

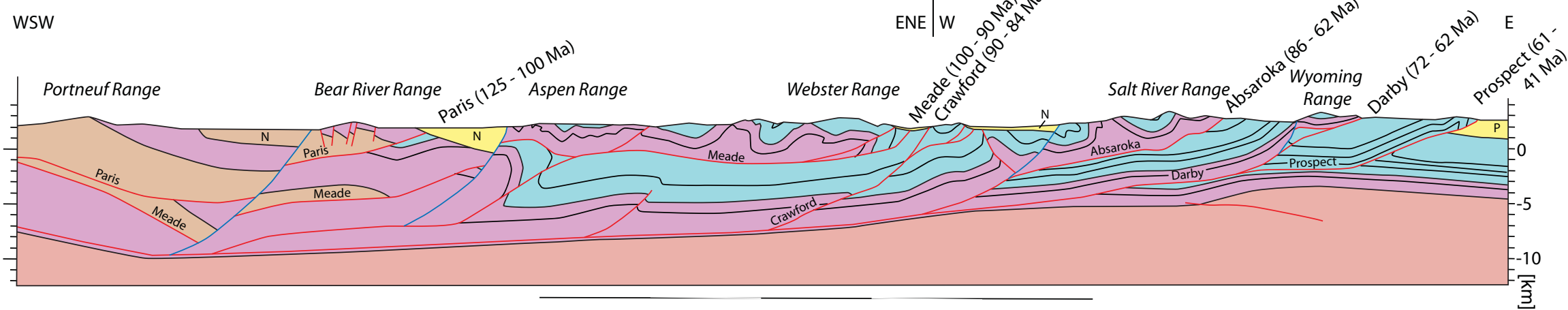

$50 \mathrm{~km}$

Cenozoic synorogenic clastics (P: Palaeogene, N: Neogene)

Mesozoic sediments (Triassic, Jurassic, Early \& Late Cretaceous)

Palaeozoic sediments (Early \& Late Palaeozoic)

Proterozoic metasediments (Windermere Supergroup)

Crystalline basement

Thrust fault Age of activity

\section{Prospect mid-Paleocene - Early Eocene}

Darby Maastrichtian - Early Paleocene

Absaroka Santonian - Early Paleocene

Crawford Coniacian-Santonian

Meade Cenomanian - Turonian

Paris Aptian - Albian

(b)

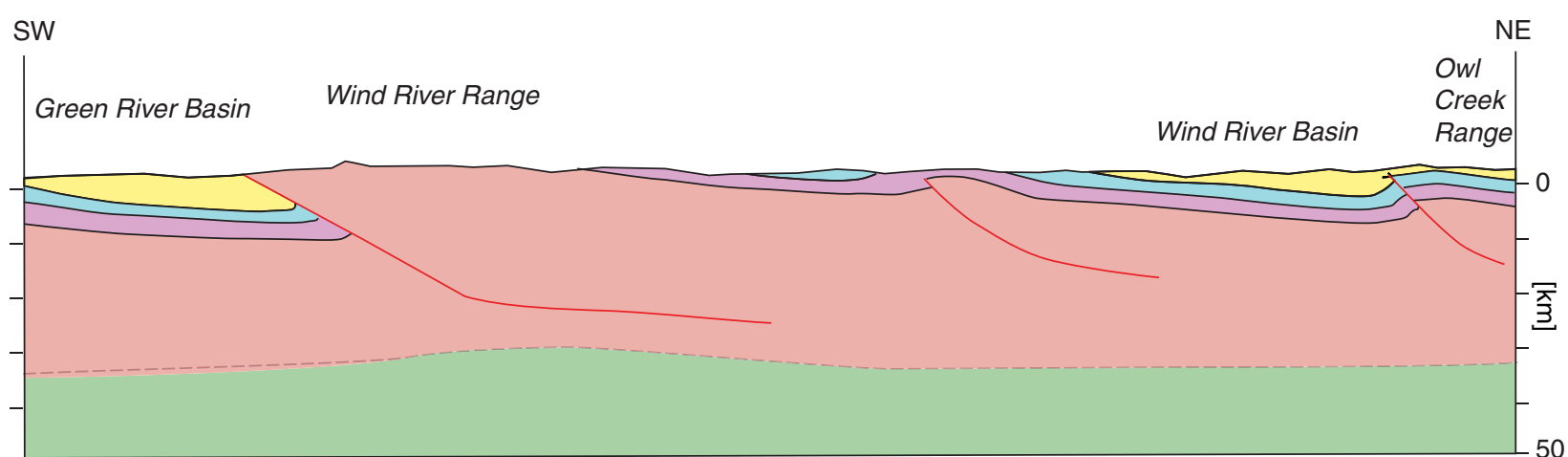

NE

reek $-0$

50

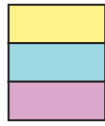

Cenozoic

Cretaceous

Palaeozoic

sediments

$50 \mathrm{~km}$

Figure 1. (a) Thin-skinned tectonic style in the Sevier fold-and-thrust belt (Wyoming). Redrawn from Royse (1993; section D). Ages of thrust activity and displacements after Royse (1993); number are approximate. Extensional faults are shown in blue. (b) Thick-skinned tectonic style in the Laramide structure (Wind River Range, Wyoming). After Smithson et al. (1978), modified. 
thrust faults were cut by younger extensional faults from Neogene time onwards.

The neighbouring Laramide structure shown in Figure $1 \mathrm{~b}$ is a classic case of thick-skinned tectonics where the thrust fault putting the Wind River Range onto the Cenozoic basin fill of the Green River Basin reaches down to at least $24 \mathrm{~km}$ (Smithson et al. 1978). It then levels off into parallelism with the crust-mantle boundary (Yeck et al. 2014). These authors suggest that the high of the Moho in the neighbouring Bighorn Mountain region is an old feature not linked to the thickskinned Laramide shortening. As shown in Figure 1b, the Moho is not cut by the Wind River thrust. The Moho high drawn in Figure $1 \mathrm{~b}$ is adapted from the topography reported by Yeck et al. (2014). It is interesting to note that the Laramide shortening occurred contemporary with some of the shortening in the Sevier orogeny, although the vergence of thrusting was opposite in the two cases.

Generally speaking the Alps can be subdivided into three segments. The Western Alps (Italy and France) extend form Nice to Geneva and have structures trending more or less $\mathrm{N}-\mathrm{S}$. The Eastern Alps (Austria and Italy) extend from the Vienna Basin to the west to Chur. Here structures are trending more or less E-W. The Central Alps (Switzerland and Italy) between Chur and Geneva make the transition between the Western and Eastern Alps.

The Alps formed in response to the subduction and collision of the European and Adriatic continental margins. The collision was preceded by subduction of a Jurassic ocean (Liguria-Piemont Ocean), the amalgamation of a microcontinent (Briançon Swell) and a basin that formed on the thinned continental European margin interspersed with small oceanic pull-aparts (Valais Basin; Steinmann, 1994; Steinmann \& Stille, 1999). The nappe systems that formed in the process reflect the crustal structure of these palaeogeographic realms. The Helvetic and Dauphinois nappe systems correspond to the shortened European margin; the Penninic nappe system evolved from the Valais Basin, the Briançon Swell and the Liguria-Piemont Ocean; and, finally, the Austroalpine and Southalpine nappe systems represent the shortened Adriatic margin. The tectonic map of Figure 2 displays the spatial arrangement of these nappe systems.

The Helvetic and Dauphinois nappe systems straddle the western and northern rim of the Alps; the Jura Mountains can be considered as a most frontal thrust sheet of this complex. The Southalpine and Austroalpine thrust systems are located on the southern margin of the Alps, but extend across the entire Alps in the Eastern Alps. Three windows, the Rechnitz, Tauern and Engadin windows, bear witness to the fact that the Penninic nappe system and the European margin extend all the way eastwards to the Vienna Basin beneath the Austroalpine nappe system. The zigzagging eastern limit of the Austroalpine north and south of Chur is an erosional front which reflects the easterly plunge of the nappe sheets of the Central Alps. The Dent Blanche klippe between Geneva and Milan along with small klippen not shown in Figure 2 testify to the fact that units derived from the Adriatic margin once covered the Penninic nappe system. The Penninic nappe system overlies the Helvetic and Dauphinois nappe system. East of Geneva and along the northern rim of the Central Alps, klippen of Penninic nappes demonstrate that these nappes once covered much of the Central Alps. The Penninic nappe system was derived from three palaeogeographic domains, the Valais Basin, the Briançon Swell and the Liguria-Piemont Ocean, which explains the differences in their internal structure.

The tectonic map of Figure 2 also shows the distribution of pre-Triassic crystalline basement rocks and Palaeozoic sediments within the different nappe systems. In the Helvetic and Dauphinois nappe systems crystalline basement crops out in the cores of antiforms that span the central part of the Western and Central Alps and include the heart of the Eastern Alps in the Tauern Window. Within the Penninic nappe system, crystalline basement crops out in the internal part of the Western and Central Alps. The Southalpine and Austroalpine nappe systems lack crystalline basement in the external part of the Alpine orogen.

The aim of this paper is to discuss the involvement of crystalline basement in the Alpine nappe structure. Apart from purely geometric aspects, the process of nappe formation is discussed in terms of the geodynamic evolution of the Alps. The study then sheds light on the influence of mechanical properties of the rock types within the nappes on the structure of these nappes.

\section{Alpine nappe structure}

In this section the structure of Alpine nappes is discussed in the light of the degree of involvement of crystalline basement rocks. This is based on a number of thrust sheets selected from the different nappe systems, which are taken to be typical for the question addressed.

\section{2.a. Helvetic nappe system}

The Helvetic nappe system comprises from top to bottom three major units: the Ultrahelvetic slices, the Helvetic nappes proper and the Infrahelvetic complex. The Ultrahelvetic slices are made of Cretaceous-Eocene sediments that were detached from their substratum and came to rest on the future Helvetic nappes. The Helvetic nappes proper were detached from their crystalline basement and transported over distances of up to $50 \mathrm{~km}$ and now overlie the Infrahelvetic complex and the Subalpine Molasse. The Helvetic nappes consist of mainly Mesozoic sediments, which are internally folded and in part dismembered into smaller thrust sheets. The Infrahelvetic complex is made up of crystalline basement (the Aar massif) with its autochthonous and parautochthonous Mesozoic and Cenozoic cover as well as some allochthonous units, which were stripped off the footwall and dragged along the basal thrust 


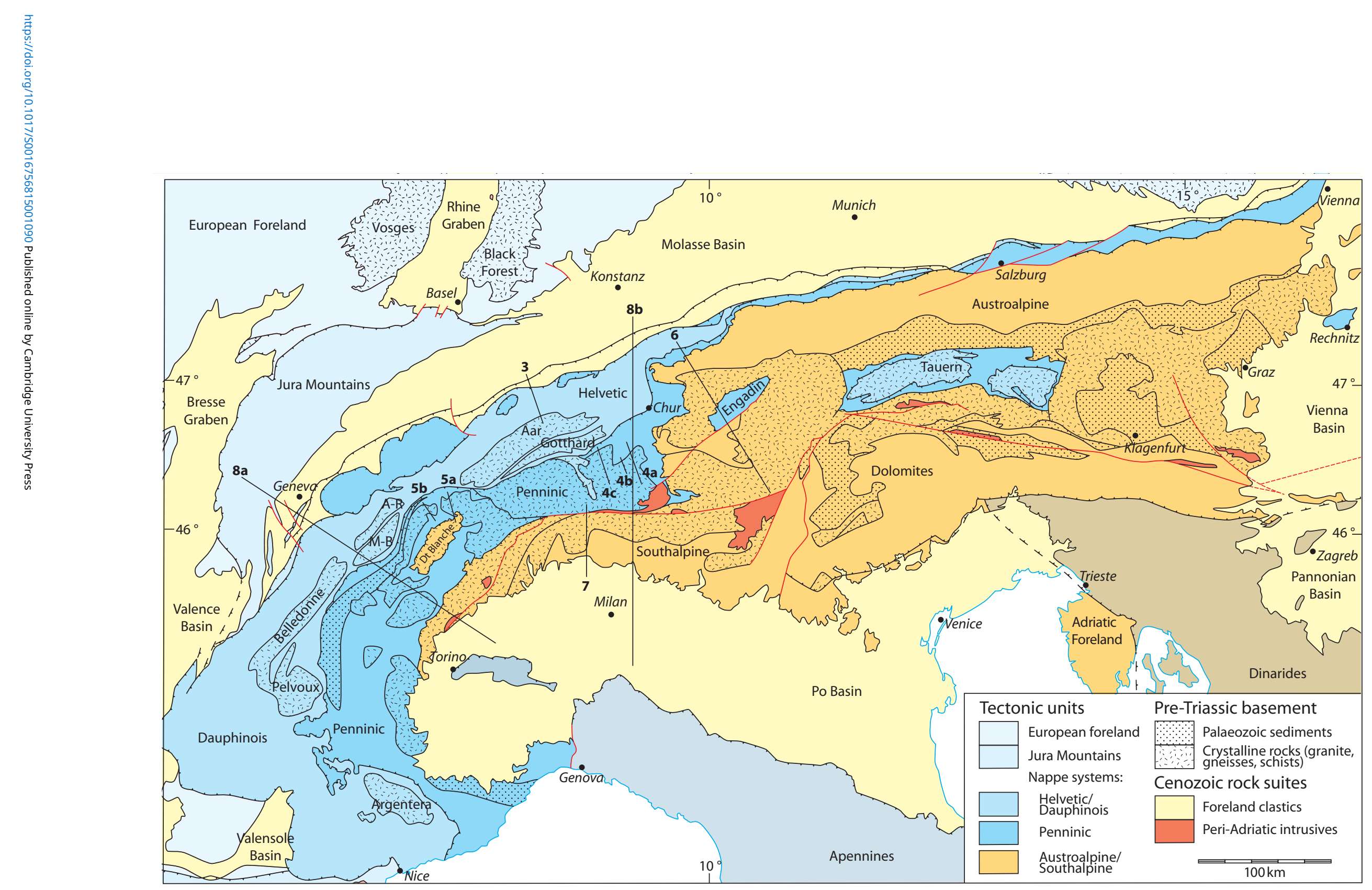

Figure 2. Schematic tectonic map of the Alps showing the main nappe systems and the distribution of crystalline basement rocks within the nappe systems. A-R - Aiguilles Rouges massif; M-B Mont Blanc massif. Labels of traces of cross-sections correspond to figure numbers. 
of the Helvetic nappes. The internal structure of the Helvetic nappe system undergoes profound changes along strike. Some of these changes occur across NS-oriented wrench faults that were active during nappe formation and allowed the independent development of structures on either side of the fault. For details regarding these structures and their changes, the reader is referred to the compilation by Pfiffner et al. (2010) and Pfiffner (2011), or the overview given in Pfiffner (2014).

The youngest synorogenic sediments involved in thrusting give a minimum age of Early Eocene in the more internal, Ultrahelvetic part, and Early Oligocene in the external part (Pfiffner, 1986; Burkhard, 1988; Schmid et al. 1996; Burkhard \& Sommaruga, 1998; Kempf \& Pfiffner, 2004). The trailing end of the Helvetic nappes was metamorphosed to an epizonal degree, the leading edge to a diagenetic degree only (Groshong, Pfiffner \& Pringle, 1984; Frey \& Ferreiro Mählmann, 1999). The underlying Infrahelvetic complex reached anchizonal to epizonal conditions. The metamorphic isograds cross-cut the internal structure of the nappe system, but are offset along the basal thrust of the Helvetic nappes (op. cit.). This metamorphism is dated as Oligocene to Miocene (see Frey \& Ferreiro Mählmann, 1999 and references therein). Combined with the stratigraphic data it points to a northward encroachment of the Helvetic nappe system onto the subsiding foreland (see also Pfiffner, 2014 and references therein).

The Helvetic nappes represent a classic thin-skinned style with Mesozoic sediments detached from their pre-Triassic crystalline substratum. Figure 3 shows a cross-section through central Switzerland highlighting the typical structures of the Helvetic nappe system. The cross-section is based on J.-W. Menkveld (unpub. Ph.D. thesis, Univ. Bern, 1995), Hänni \& Pfiffner (2014) and Pfiffner \& Deichmann (2014). In the case of the Axen thrust shown in Figure 3, decollement occurred in Triassic evaporites, Lower Jurassic shales and Middle Jurassic shales, whereby the thrust fault climbed in a stepwise fashion to successively higher levels in the direction of transport. Within the Axen nappe south of Gross Walenstock in Figure 3, the relatively thick Lower and Middle Jurassic strata led to the development of detachment folds. These mechanically weak strata filled the cores of anticlines that developed in the mechanically strong Upper Jurassic limestones. Beneath and north of Gross Walenstock the Upper Jurassic limestones form an imbricate stack; here the mechanically weak layers are thin such that the formation of detachment folds was inhibited. The causal relationship between the thickness of detachment horizons and the formation of detachment folds and/or thrust faults is discussed in Pfiffner (1993). This study suggests that the ratio, $n$, of the thickness of mechanically weak to the thickness of mechanically strong layers is of importance regarding the style of a fold-and-thrust belt. A low ratio favours harmonic folding and/or imbricate thrusting, whereas ratios greater than 0.5 lead to disharmonic folding and the formation of detachment folds.

As evident in the cross-section of Figure 3, the Cretaceous strata extend much further to the north owing to differential movement along the Drusberg thrust, which followed the decollement horizon located in the marls of the Palfris Formation. Within the Drusberg nappe, the Cretaceous limestones above the decollement form detachment folds south of Bürgenstock and north of Gross Walenstock. The fact that the folds in the Axen and Drusberg nappe are disharmonic suggests that the decollement of the Cretaceous strata occurred at the very onset of nappe formation. The decoupling was controlled by the greater thickness of the Palfris Formation on the subsiding European margin in the south of the Helvetic realm. In the Axen nappe, Cretaceous strata are folded just north of Gross Walenstock; these folds change from detachment fold style to imbricate thrusting as the Palfris Formation tapers off towards the north.

The question that arises is which crystalline basement formed the original substratum of these Helvetic nappes. Since the underlying Aar massif retained its autochthonous cover this basement is to be sought further to the south (Trümpy, 1969; Kempf \& Pfiffner, 2004). In fact, as evident on geological maps, on the southernmost Aar massif, the Tavetsch massif and the Gotthard massif the autochthonous Mesozoic cover is missing except for lenses of Triassic strata that now delimit these basement blocks.

Inspection of Figure 3 reveals that the Aar massif is updomed in the hanging wall of a thrust fault that puts the Aar massif onto the autochthonous foreland. This bulging is a late feature in the structural evolution and was responsible for the passive updoming of the Axen thrust. The thick-skinned nature of this structure will be discussed later in the framework of the entire Alpine orogen.

North of and beneath the Drusberg nappe the Molasse sediments exhibit an imbricate structure giving way to an antiformal structure north of Lake Lucerne. This shortened package of Molasse sediments that is overridden by the Helvetic nappes is called Subalpine Molasse in the literature. The clastic sequence involved was deposited in a foredeep that formed during nappe stacking in the ancestral Alps. The decollement of the thrust sheets occurred in a thick Oligocene mudstone sequence (the so-called Lower Marine Molasse, UMM). The northernmost thrust fault within the Subalpine Molasse is tentatively linked to the basal thrust fault of the Aar massif in Figure 3. The structure shown at the transition of the Northhelvetic Flysch to the Subalpine Molasse in Figure 3 is speculative. It can't be studied at outcrop, has not been drilled and the available reflection seismic lines (Pfiffner, Sahli \& Stäuble, 1997) are not conclusive for this particular question.

In the Western Alps, Boutoux et al. (2014) reported that the updoming of the external massifs was strongly controlled by the Jurassic rift basins. Deformation 


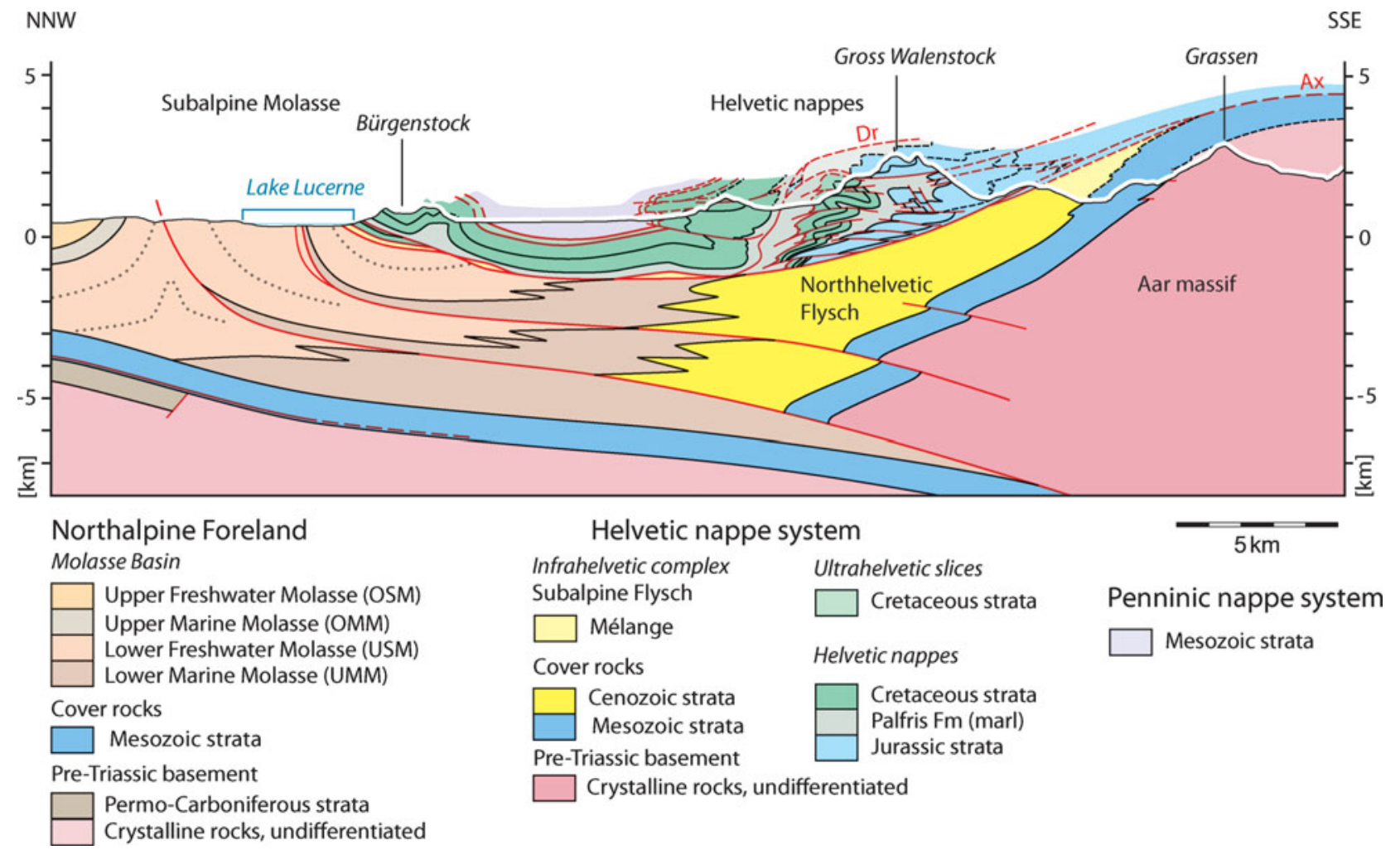

Figure 3. Cross-section of the Helvetic nappe system and the Subalpine Molasse in central Switzerland. See text for discussion. Trace of cross-section is given in Figure 2. Ax - Axen thrust; Dr - Drusberg thrust.

within the crystalline basement involved localized shear zones that link to tight folds in the sedimentary cover above. According to these authors, Jurassic rifting weakened the crust and concentrated deformation during the Alpine orogenesis.

\section{2.b Penninic nappe system}

The Penninic nappe system, located in the very core of the Alpine chain, is by far the most complex of all. Generally speaking, three types of nappes may be distinguished based on the rock suites involved: crystalline basement nappes, sediment nappes and ophiolite nappes. As will be shown, a clear distinction is not always possible.

Crystalline basement nappes consist of polymetamorphic gneisses interspersed with amphibolites and late- to post-Variscan granitoids now preserved as orthogneisses. Sediments are rare and usually consist of Triassic quartzites and carbonates that occur as thin lenses traceable over long distances. They allow for the separation of the various crystalline basement nappes (they are referred to as 'nappe separators' in early Alpine literature). The sediment nappes display mostly a very complex geometry owing to a multiphase deformation (including post-nappe folding). Ophiolite nappes emanating from the ocean basins that opened in the Jurassic-Cretaceous period crop out as lenses several kilometres long and are typically associated with deep-water sediments.
The Penninic nappe system attained a much higher degree of metamorphism compared to the Helvetic nappe system discussed in Section 2.a above. In the Lepontine area of the Central Alps upper-amphibolite grade is reached. The isograds of this Barroviantype metamorphism cross-cut the nappe boundaries. Peak temperatures were reached in latest Eocene time (between 35 and $30 \mathrm{Ma}$ ) most likely (see discussion in Frey \& Ferreiro Mählmann, 1999). It is important to note that this regional metamorphism was preceded by a high-pressure event in Late Eocene time from 45 to $35 \mathrm{Ma}$ (see e.g. Rosenbaum \& Lister, 2005). It is important to note though that, considering the entire Alpine orogeny, the high-pressure metamorphism is diachronous. It is of mid Cretaceous age $(\sim 100 \mathrm{Ma})$ in the Eastern Alps and latest Cretaceous (70 Ma) to Palaeogene (50 to $35 \mathrm{Ma}$ ) in the Western and Central Alps (see metamorphic map by Oberhänsli et al. 2004).

The structural evolution is characterized by multiphase thrusting and folding. Deformation phases as determined from structural analyses vary from area to area and it is often very difficult to correlate from one study area to the next. Such correlations are also hampered by the fact that deformation phases are defined by map patterns in some instances and by microstructures in other cases. Moreover, some authors put emphasis on folds (e.g. Steck et al. 2013) while others emphasize the importance of thrusting in nappe stacking (e.g. Manzotti et al. 2014). The tectonic evolution of the Penninic nappes of the Central Alps is discussed in more detail in Schmid et al. (1996) and 
Scheiber, Pfiffner \& Schreurs (2012) for the eastern part, and in Burkhard \& Sommaruga (1998), Scheiber, Pfiffner \& Schreurs (2013) and Steck, Masson \& Robyr (2015) for the western part. A larger scale compilation of the structural syntheses and the timing of orogenic events for the Eastern, Central and Western Alps is given in Pfiffner (2014). This compilation reveals that generally speaking the detachment of sedimentary cover nappes occurred in an early stage and was followed by thick-skinned tectonics involving the crystalline basement. For the Penninic nappe system, nappe stacking commenced in mid Eocene times and postnappe folding lasted into Early Miocene time.

In the following, priority is given to the basement nappes within the Penninic nappe system as these relate rather directly to the topic of thin- and thick-skinned tectonics.

\section{2.b.1. Suretta nappe}

The first example, the Suretta nappe, crops out in the eastern Central Alps and is discussed using the crosssection shown in Figure 4a. The cross-section is based on the work of Scheiber, Pfiffner \& Schreurs (2012), Schreurs (1995) and Milnes \& Schmutz (1978). It shows the internal structure of this nappe, which is characterized by intensive back-folding that affected the upper part of the nappe. Remnants of autochthonous cover (Triassic quartzites and marbles) are preserved in the upper part of the nappe but extend deep into the crystalline basement and outline nearly isoclinal folds. The contact with the sediments beneath the Suretta nappe, the Schams nappe in the north, the Andossi slice in the south (see Fig. 4a), is clearly of a tectonic nature. The crystalline basement of the Suretta nappe contains a Permian intrusive complex (Rofna Porphyry complex) that is restricted to the northern part of the nappe. A major thrust fault outlined by Triassic sediments splits the frontal part of the nappe into two units (Fig. 4a).

The contact of the autochthonous cover in the upper unit of the nappe with the overlying nappes (Schams nappe and Avers nappe; see Fig. 4a) is of a thrust nature, and the thrust fault is clearly affected by the nappeinternal folds of the Suretta nappe (Milnes \& Schmutz, 1978). It may hence be concluded that the younger Mesozoic cover of the Suretta nappe was removed and replaced by an allochthonous cover of more internal origin (Piemont Ocean in the case of the Avers nappe).

The Schams nappe that wraps around the Suretta nappe at the front consists of a sequence of Mesozoic sediments that was deposited on the Briançon Swell. These rocks were detached from their crystalline substratum in an early stage: the subduction phase of the Cenozoic Alpine orogeny in Middle Eocene time. As discussed by Schmid, Rück \& Schreurs (1990), the crystalline substratum of the Schams nappe is to be sought in the Suretta and Tambo nappes. These basement nappes were later forced into the Schams nappe in a later phase of subduction in Late Eocene time, and led to the formation of the back-folds in the Suretta nappe.

\section{2.b.2. Tambo nappe}

The second example of Penninic basement nappes is the Tambo nappe, for which the northern part is shown in the cross-section of Figure $4 \mathrm{~b}$. The cross-section is based on the work of Mayerat-Demarne (1994). On top of the Tambo nappe small remnants of Triassic quartzites is all that remains of the autochthonous cover. The Triassic marbles and cargneules (altered gypsum-bearing evaporites) of the Andossi slice located between the Tambo and Suretta nappes represent an allochthonous sequence that has been scraped off the southern part of the Tambo nappe and piled up as imbricate slices.

The Knorren mélange at the front of the Tambo nappe is a chaotic mix of lenses of boulders of metabasalts, gneisses, polymict breccias (containing gneisses), quartzites, marbles, dolostones, evaporites and calcareous sandstones embedded in a matrix of black and green slates, sandstones and marble. This mélange could have formed during Jurassic normal faulting or in the course of Alpine nappe stacking, or as a combination of the two processes (Mayerat-Demarne, 1994).

A particularly interesting feature is the intricately folded 'sandwich' to the north of the Knorren mélange. Here Mesozoic sediments pertaining to the Schams nappe are sandwiched between two thin basement flakes. The contact between the sediments and the basement is of a tectonic nature. But it remains so far unclear if it is related to the formation of extensional allochthons during Jurassic normal faulting, Alpine nappe stacking or both. The contact with the sediments of the Tomül nappe, however, is clearly a thrust fault. Therefore, the tight folding of the 'sandwich' represents post-nappe folding. It may be correlated to the back-folding phase which affected the Suretta nappe as discussed above.

\section{2.b.3. Adula nappe complex}

The third example, the Adula nappe complex, underlies the Tambo nappe and has a far more complex internal structure that is characterized by a manifold repetition of slabs of ortho- and paragneisses (Berger \& Mercolli, 2006; Cavargna-Sani et al. 2014a; Pleuger \& Podladchikov, 2014). As pointed out by Nagel (2008), the gneisses of the Adula nappe complex show a mylonitic Alpine foliation in comparison to the more moderately deformed gneisses of the Simano nappe beneath and the Tambo nappe above. The cross-section shown in Figure $4 \mathrm{c}$ is based on a horizontal section provided by Löw (1987). The advantage of using a horizontal section is the relatively short projection distances of the structural features observed at outcrop. The horizontal section was then telescoped in the direction of the general ENE-directed plunge of the large-scale fold axes 

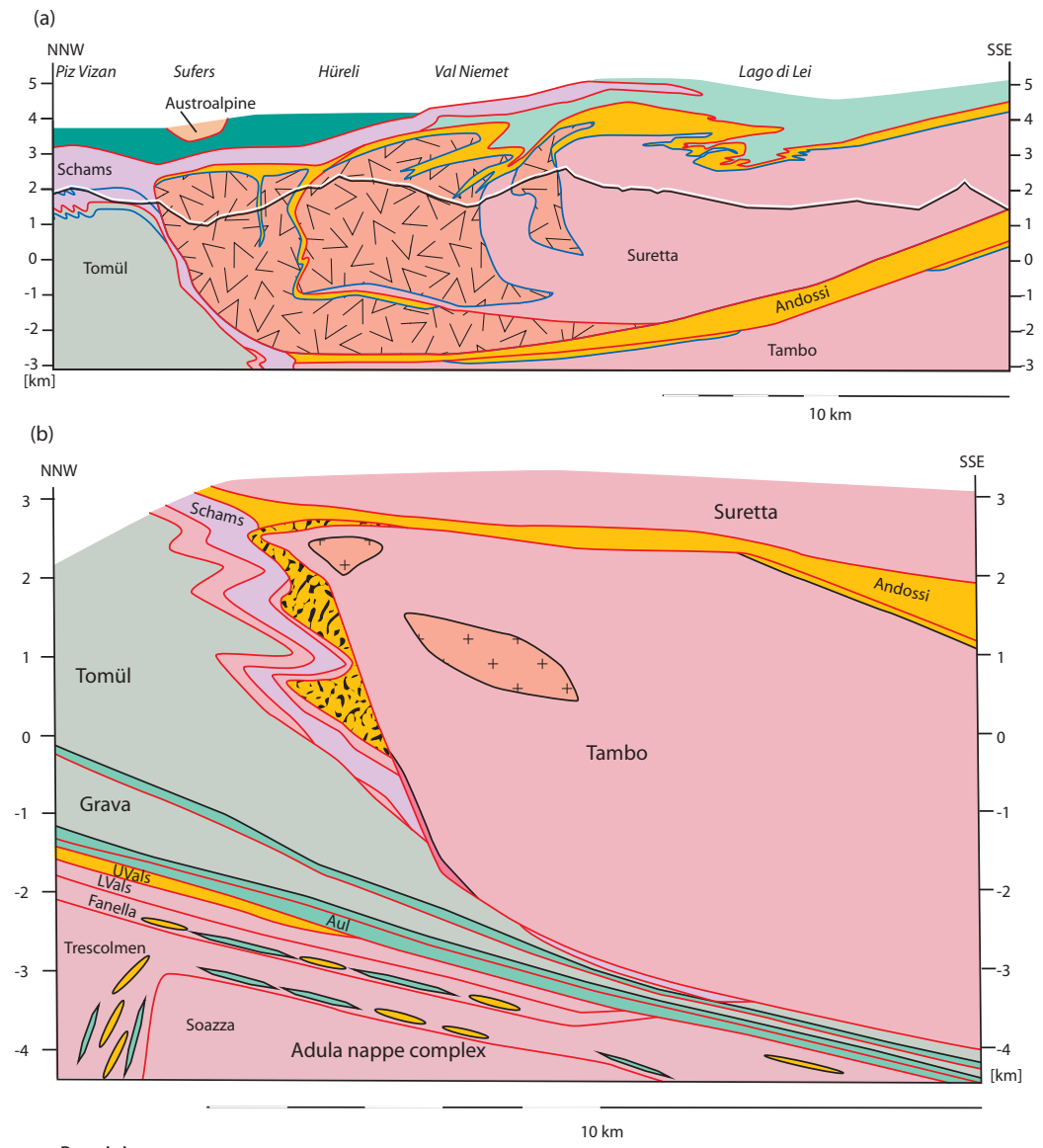

Penninic nappe system
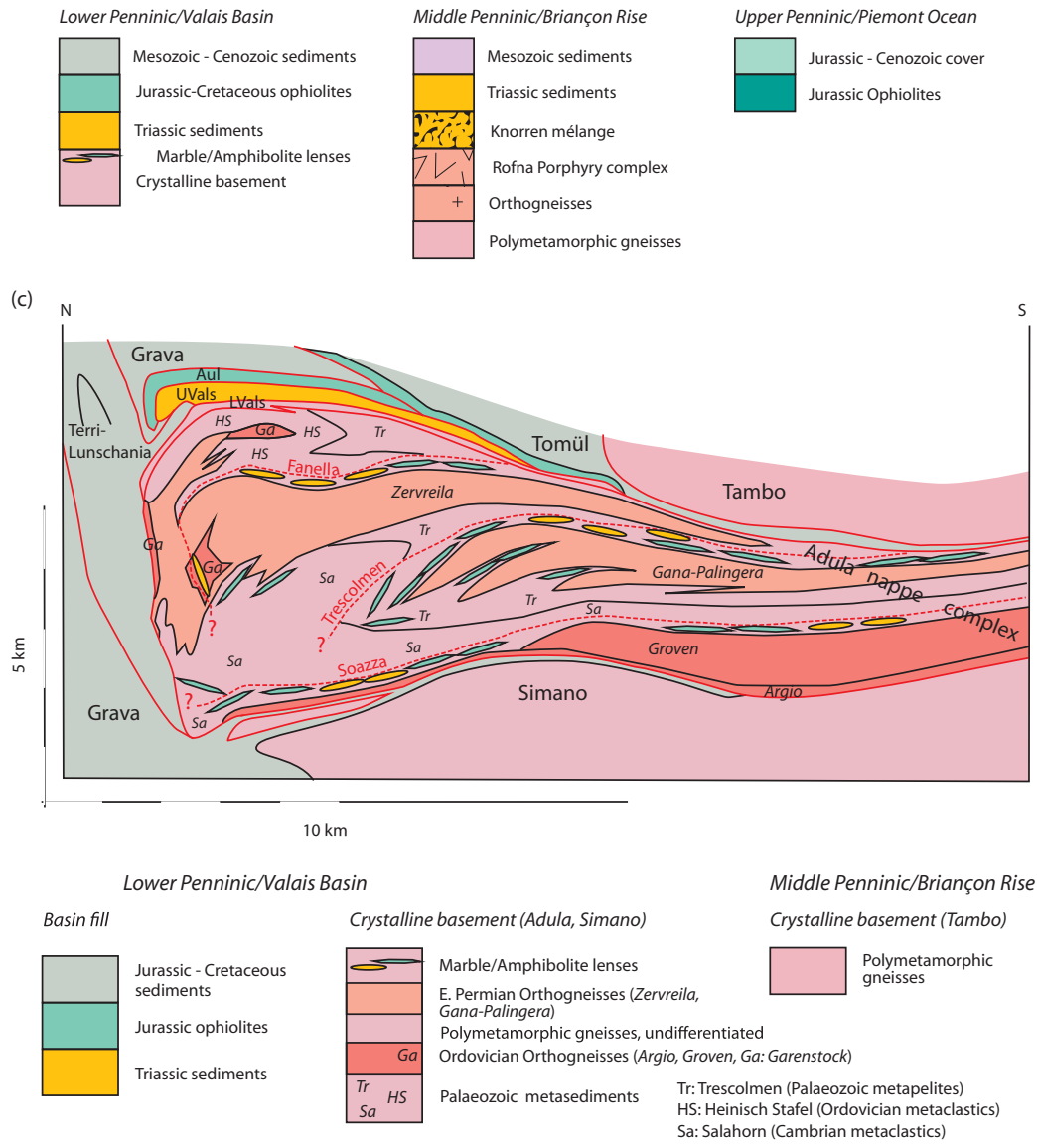

Figure 4. Cross-sections of the Penninic basement nappes in eastern Switzerland. See text for discussion. (a) Suretta nappe. (b) Tambo nappe. (c) Adula nappe system. Traces of cross-sections are given in Figure 2. 
in order to obtain a cross-sectional geometry as one would obtain in a vertical cross-section. The plunge of the structures is corroborated by the reflection seismic data of NRP20 acquired 15 to $50 \mathrm{~km}$ east of the Adula outcrops (see Pfiffner \& Hitz, 1997).

The general structure of the front of the Adula nappe complex with panels of orthogneisses interlayered with polymetamorphic paragneisses was projected into the cross-section of Figure $4 \mathrm{c}$ using the horizontal section of Löw (1987), the tectonometamorphic map of Berger \& Mercolli (2006) and the map by Cavargna-Sani et al. (2014a). Five major orthogneiss complexes are recognized: Zervreila, Gana-Palingera, Groven, Argio and Garenstock. Their contacts with the paragneisses are in part very complex, and owing to the intensive Alpine overprint these orthogneiss complexes cannot be interpreted in terms of intrusive bodies. Cavargna-Sani et al. (2014a) combined the Groven and Argio complexes into one complex (Rossa Orthogneiss) and consider Gana-Palingera to be part of Zervreila. They were able to date the Garenstock and combined Groven and Argio complexes as Ordovician (Garenstock to 457-446 Ma; Groven-Argio to 459-456 Ma), whereas the Zervreila complex is of Early Permian age (297-288 Ma). These authors were also able to further subdivide the paragneisses (see Fig. 4) into formations and to date these. The Salahorn Formation and Heinisch Stafel Formation, two sequences of metaclastic and magmatic rocks, were dated to be of Cambrian and Ordovician age, respectively. The Trescolmen Formation is made of metapelites containing mafic lenses and is of Palaeozoic age.

A peculiar feature contained within the paragneiss panels are the lenses of marble, as well as lenses of (partly eclogitic) amphibolites within metapelites, which are lined up forming strings of pearls in the roof of the orthogneiss complexes. The repartition of these lenses within the Adula nappe complex shown in the cross-section is based on the map by Berger \& Mercolli (2006). In some instances, groups of marble and amphibolite lenses occur side by side. Cavargna-Sani et al. (2014a) dated one lens to be of Ordovician age. The carbonate lenses are in part possibly of Palaeozoic age (Cavargna-Sani et al. 2014a), but most of them are likely to be of Mesozoic age (Nagel et al. 2002; Berger \& Mercolli, 2006; Cavargna-Sani, Epard \& Steck, 2014). Cavargna-Sani et al. (2014a) suspected that the Trescolmen Formation with its Palaeozoic mafic lenses represents a tectonic mélange related to terrane accretion or subduction. But it has to be noted that in the case of the Fanella and Trescolmen units the lenses straddle the boundary between Palaeozoic paragneisses above and post-Variscan orthogneisses below. Similarly, the Cambrian Salahorn Formation overlies the Ordovician orthogneisses of the Groven-Argio complex in the case of the Soazza unit. The contacts marked Fanella, Trescolmen and Soazza in Figure 4c extend over 10 and more kilometres towards the south, retaining the nature of putting older rocks onto younger rocks. Of particular interest is the presence of Triassic carbonate lenses along these contacts, which suggests that these contacts are thrust faults that formed in an early stage of nappe stacking (Zapport Phase; see e.g. CavargnaSani, Epard \& Steck, 2014). It may well be that parts of the mafic lenses next to the carbonate lenses are also of Mesozoic age and represent remnants of ophiolites related to the Valais Basin.

As Cavargna-Sani, Epard \& Steck (2014) have shown, intensive shearing and folding characterize the internal structure of the northern Adula nappe. This post-nappe folding affected the internal structure of the northern Adula nappe profoundly. Nevertheless, an early imbrication cannot be ruled out (Pleuger \& Podladchikov, 2014) and is also supported by the structure of the southern Adula nappe and the adjacent Southern Steep Belt where Engi, Berger \& Roselle (2001) reported the existence of a mélange including lenses of mantle material; these authors explained this structure as having formed in a tectonic accretion channel (TAC) along the Eocene plate boundary ('Alpine lithospheric mélange' of Trommsdorff, 1990).

The Mesozoic cover sediments of the basement slivers now forming the Adula nappe complex have been detached to form a nappe pile of their own. These cover sediments now form the Grava, Terri-Lunschania, Aul, Tomül, and the Upper and Lower Vals imbricates shown in Figure 4c. This nappe pile is affected by significant post-nappe folding as indicated by isoclinally folded thrust faults (e.g. Probst, 1980; Wiederkehr et al. 2008). The Aul and Tomül imbricates contain Mesozoic ophiolites (Tomül at the base only).

\section{2.b.4. Bernard nappe complex}

The fourth example of Penninic basement nappes discussed is the Bernard nappe complex of the western Central Alps (Fig. 5). The structure of this nappe complex has been elaborated on by generations of geologists (see Scheiber, Pfiffner \& Schreurs, 2013 and references therein). The Bernard nappe complex is subdivided into a lower unit, the Siviez-Mischabel nappe, and an upper unit, the Mont Fort nappe. It is presented using two cross-sections based on the work by Scheiber, Pfiffner \& Schreurs (2013). The eastern cross-section (Fig. 5a) contains the lower unit only: the Siviez-Mischabel overlying the Mesozoic carbonates of the Zone Houillère (formerly attributed to the Pontis nappe, which was also considered part of the Bernard nappe complex). The Siviez-Mischabel nappe has a core made of pre-Triassic basement rocks (mainly Palaeozoic paragneisses), which is overlain by an autochthonous cover of Permo-Triassic and Triassic quartzites and Jurassic carbonates and shales. A thick sequence of mainly quartzites can be found beneath the crystalline basement rocks. Because of the seemingly symmetric structure with an upper and lower limb of sediments on either side of the crystalline basement, the Siviez-Mischabel nappe was interpreted to represent a large-scale recumbent fold (e.g. Argand, 1916; Escher, Masson \& Steck, 1993; a detailed discussion is given in Scheiber, Pfiffner \& Schreurs, 2013). However, as 


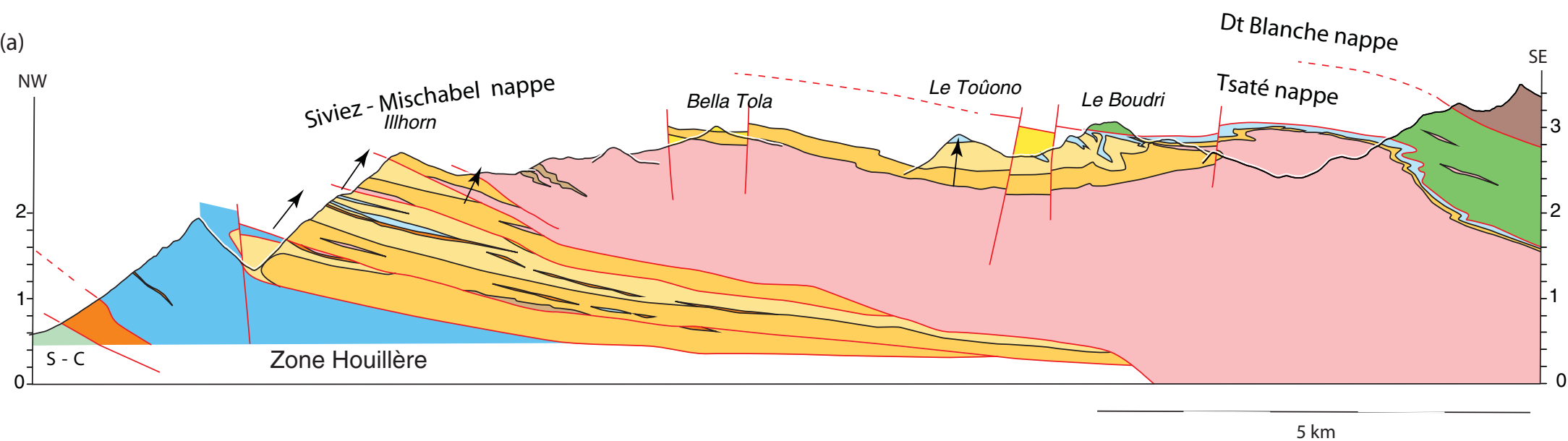

(b)

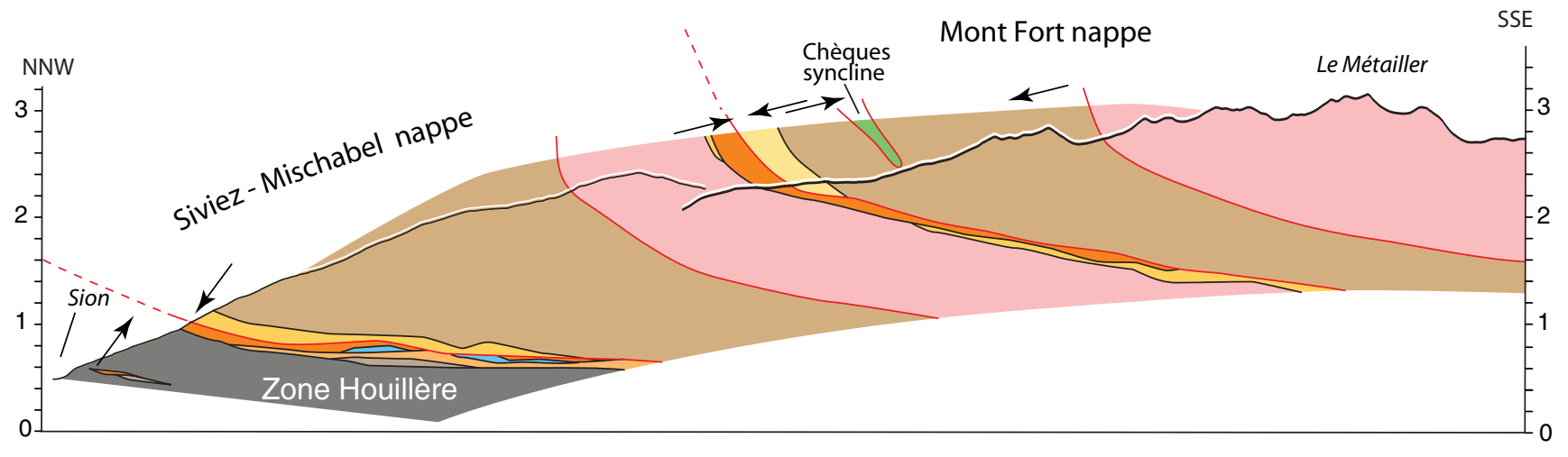

Bernard nappe complex

Mont Fort \& Siviez-Mischabel nappe

Dent Blanche nappe

Tsaté nappe

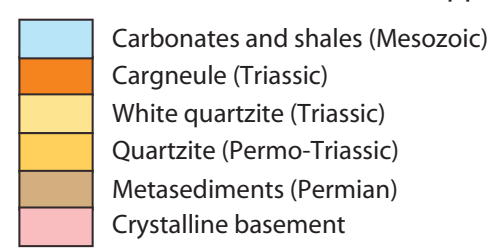

Zone Houillère

$\square$ Carbonates (Mesozoic)

Cargneule (Triassic)

Quartzite (Triassic)

Metasediments (Permo-Triassic)

Sion-Courmayeur zone

Metasediments (Carboniferous)

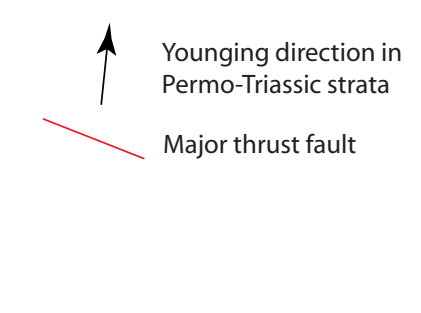

Figure 5. Cross-sections of the Bernard nappe complex in western Switzerland. See text for discussion. (a) Eastern section (Val d'Anniviers). (b) Western section (Val d'Hérémence). Traces of cross-sections are given in Figure 2. 
Markley, Teyssier \& Caby (1999) and Scheiber, Pfiffner \& Schreurs (2013) have shown, the sedimentary sequences beneath the crystalline basement represent a stack of imbricate thrust sheets where the sediments are in an upright position (as indicated by the arrows in Fig. 5). They are interpreted as having been detached from their crystalline substratum, piled up and subsequently overridden by their former substratum. Several lenses of Permian metasediments are found within the quartzites and the basement and point to pervasive internal imbrications and shearing. The basal thrust of the Tsate nappe is folded harmonically with the folds in the cover of the Siviez-Mischabel nappe, which proves that the emplacement of the Tsaté nappe occurred in an early stage of nappe stacking. The Tsaté nappe is an upper Penninic unit derived from the Piemont Ocean (e.g. Sartori, Gouffon \& Marthaler, 2006), and the overlying Dent Blanche nappe consists of crystalline basement attributed to the Adriatic margin, i.e. to the Southalpine nappe system (cf. Manzotti et al. 2014).

The cross-section shown in Figure 5b looks rather different even though it is located only about $23 \mathrm{~km}$ further to the WSW. Here the Bernard nappe complex is represented by an additional nappe, the Mont Fort nappe. Both, the Siviez-Mischabel and the Mont Fort nappe contain a thick sequence of Permian metasediments. It is in fact the termination of these Permian basins (graben structures) that causes the change in the internal architecture (see Scheiber, Pfiffner \& Schreurs, 2013 for a more detailed discussion). The Permian metasediments are in a stratigraphically inverted position owing to the inversion of the Permian graben. Nevertheless, the crystalline basement of the SiviezMischabel has an autochthonous cover of Permian and Triassic quartzites, whereas the younger Mesozoic cover was detached and can now be found in the Klippen nappe in the more external part of the Alps (Ellenberger, 1952; Sartori, 1987; Stampfli, 1993; Sartori, Gouffon \& Marthaler, 2006). The contact with the Permian metasediments below this crystalline basement is of a thrust nature (Scheiber, Pfiffner \& Schreurs, 2013). In the Mont Fort nappe, a thin synform of the Tsaté nappe pinched between the Permian metasediments points to intensive folding and shearing of the Permian. Stratigraphic younging directions suggest the presence of an anticline to the north of the synform. The contact with the crystalline basement of the upper part of the Mont Fort nappe is of a thrust nature again, but the Permian beneath has been overturned in the course of basin inversion.

All in all, the western cross-section indicates that the Mesozoic sequence of the Briançon Swell was detached along the Triassic evaporites (now present as cargneules). The presence of lateral mechanical discontinuities provided by Permian graben structures could explain the contrasting styles in the western and eastern cross-sections of Figure 5 (Scheiber, Pfiffner \& Schreurs, 2013); moreover, the large-scale folds in the western section may be attributed to inversion of the Permian graben structures.

\section{2.c. Austroalpine-Southalpine nappe systems}

The Austroalpine and Southalpine nappe systems are a heterogeneous structural assembly of nappes consisting of crystalline basement, Mesozoic sediments or both. Their common feature is the palaeogeographic attribution to the Adriatic continental margin. Two examples illustrating the involvement of crystalline basement in the Alpine nappe structure will be discussed in more detail.

\section{2.c.1 Silvretta-Sesvenna-Campo nappe complex}

The Austroalpine nappe system in the Eastern Alps forms an orogenic lid covering the underlying Penninic nappe system, which crops out in three windows: the Engadin, Tauern and Rechnitz windows (see Fig. 2). The cross-section given in Figure 6 passes through the westernmost window, the Engadin Window. It illustrates the internal structure of the largest crystalline basement nappe, the Silvretta-Sesvenna-Campo nappe system, measuring about $100 \mathrm{~km}$ in a NW-SE direction. The shallow part of the cross-section is based on Oberhauser (1998) in the northwest and Schmid (1973) and Schmid \& Haas (1989) in the central part. The deep structure from the Engadin Window to the northwest is constrained by reflection seismic data (Hitz, 1996; Pfiffner \& Hitz, 1997).

To the northwest, the Silvretta basement is overthrust onto the Northern Calcareous Alps, and, according to Oberhauser (1998), the basal thrusts of both the Silvretta basement as well as the Northern Calcareous Alps are affected by folds and thrust faults emanating from the Penninic nappe system in its footwall. The internal structure of the Penninic nappe system is not shown in the cross-section, but considering crosssections further to the west (Schmid et al. 1996; Pfiffner \& Hitz, 1997), where continuous surface outcrops and reflection seismics constrain the internal structure of the Penninic nappe system, displacements along individual thrust faults between nappes are much higher (tens of kilometres) compared to the displacements of the thrust faults that offset at the base of the Austroalpine nappe system. This situation suggests the existence of an 'orogenic lid' made up of Austroalpine nappes in the hanging wall of the Penninic nappes in the course of their formation.

In the central part, the autochthonous sedimentary cover of the Sesvenna basement is preserved (Schmid, 1973), folded and partly scraped off by the emplacement of the Ötztal nappe along the Schlinig thrust in a westerly direction in Cretaceous time (Schmid \& Haas, 1989). Scraping off of the sediments in the footwall of the thrust from the Sesvenna basement involved lowangle normal faults associated with a westerly motion of the upper part of the sedimentary cover. The inset in Figure 6 is redrawn from Schmid \& Haas (1989) and displays the structure in the footwall of the Schlinig thrust. According to these authors, the cover rocks of the Sesvenna basement were horizontally stretched by 


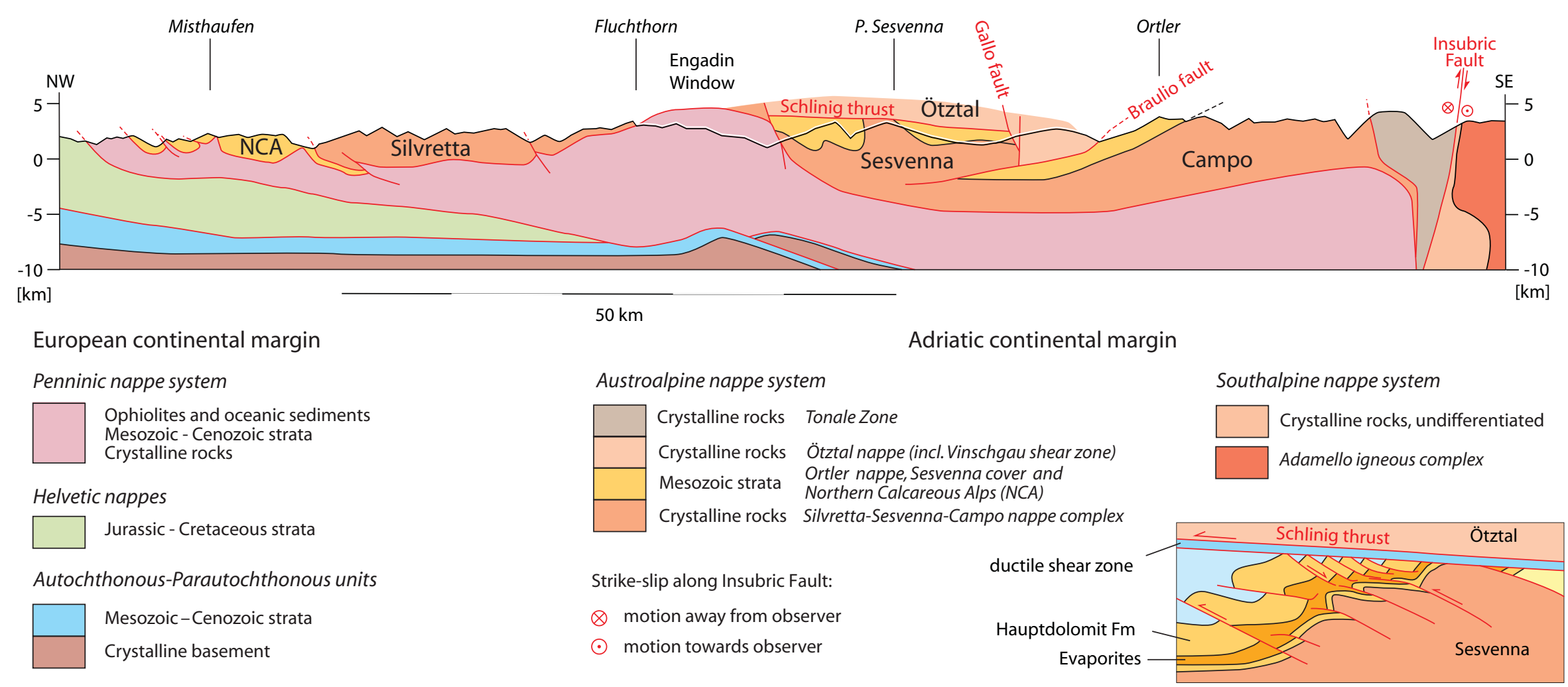

Figure 6. Cross-section of the Austroalpine nappes of western Austria. See text for discussion. Inset shows normal faulting in the cover of the Sesvenna basement related to the Schlinig thrust at the base of the Ötztal nappe (redrawn from Schmid \& Haas, 1989). Trace of cross-section is given in Figure 2. 
low-angle normal faults during the emplacement of the Ötztal basement. Towards the east, the Schlinig thrust widens into a thick ductile shear zone (Schmid \& Haas, 1989) indicating that the displacement along the thrust faults within the basement was dissipated by these shear zones. This contrasts with the sharp thrust contacts in the Penninic basement nappes discussed in the previous Section 2.b.

If the Ötztal nappe clearly overlies the Sesvenna nappe, the contacts between the Sesvenna and Campo basement are more difficult to interpret in terms of thrust sheets. As discussed by Schmid (1973), the various tectonic units are not sheets but rather blocks, which moved in different directions, and namely, the detached sedimentary cover sequences were intricately imbricated in a manner not shown in the cross-section of Figure 6. The 'double nature' of faults - strike-slip and thrust faults - is particularly highlighted by the Gallo and Braulio faults shown in Figure 6. The Gallo fault, nearly vertical in the cross-section of Figure 6, becomes a more shallow E-dipping thrust fault a few kilometres to the northeast (Schmid, 1973). The Braulio fault, NW-dipping in the cross-section of Figure 6, undergoes strike changes going west and east and rejoins the Gallo fault at some stage (Schmid, 1973).

The Campo basement and its Triassic cover in the Ortler nappe in the south rise towards the southeast. Just northwest of the Insubric fault the Campo basement forms an antiform with a steep southern limb and disappears in the subsurface. This antiform formed in response to strike-slip and reverse faulting along the Insubric fault.

\section{2.c.2 Southalpine nappe complex}

In the Southalpine nappe complex S-vergent thrusting created a thick stack of basement nappes. The sedimentary cover of these nappes remained largely attached to the crystalline substratum. The cross-section shown in Figure 7 is based on reflection seismic data of NRP20, redrawn and modified from Schumacher (1997). For all the units thrust faults formed a ramp from the crystalline basement up across the Mesozoic in their rear (northern) parts such that in the vicinity of the Insubric fault we observe a stack of basement pieces, whereas to the south, beneath the Po Basin we observe a stack consisting of Mesozoic cover rocks.

In case of the Strona-Ceneri Zone (see Fig. 7) two thrust faults of opposing vergence indicate that this basement was jammed into the basement of the Upper Orobic nappe. Similarly, at the southern front of the Upper Orobic nappe the Mesozoic carbonates were wedged into the sediments underlying the Po Basin as evidenced by the $\mathrm{N}$-vergent thrust faults.

\section{Crustal structure}

Apart from the detached upper crustal thrust sheets discussed in the preceding Section 2, new geophysical data give insight into how the lower part of the crust was af- fected by the Alpine collision event. Figure 8 shows two crustal sections across the Western and Central Alps. The lithologic contacts and thrust faults shown in the upper crust are based on geological surface data, structural considerations and interpretation of the reflection seismic lines of ECORS/CROP (Schmid \& Kissling, 2000) and NRP20 (Schmid et al. 1996; Pfiffner \& Hitz, 1997; Pfiffner, 2014).

The crustal structure shown in Figure 8 is based on controlled-source seismology (CSS) combined with local earthquake tomography (LET) (Diehl et al. 2009; Wagner, Kissling \& Husen, 2012). To highlight the crustal structure, the $P$-wave velocity contour of $6.5 \mathrm{~km} \mathrm{~s}^{-1}$ and the crust-mantle boundary (Moho) was chosen. The $v_{P}=6.5 \mathrm{~km} \mathrm{~s}^{-1}$ velocity contour is taken as a proxy for the interface between upper and lower crust, lower crust having $P$-wave velocities $\geq 6.5 \mathrm{~km} \mathrm{~s}^{-1}$ based on CSS data (Ansorge, Blundell \& Mueller, 1992). It has to be mentioned though that the resolution of the LET data is not homogeneous throughout a cross-section (Diehl et al. 2009). Also, there are some discrepancies between CSS and LET data regarding the position of the interface between the upper and lower crust (Conrad Discontinuity) derived from CSS data (Ansorge, Blundell \& Mueller, 1992) and the $v_{P}=6.5 \mathrm{~km} \mathrm{~s}^{-1}$ velocity contour. This leaves some room for interpretation for the position of the Conrad Discontinuity. In the cross-sections of Figure 8, the $v_{P}=6.5 \mathrm{~km} \mathrm{~s}^{-1}$ contour was taken to represent this discontinuity, a first-order approximation also adapted by Rosenberg \& Kissling (2013). Velocity contours for $v_{P}<6.5 \mathrm{~km} \mathrm{~s}^{-1}$ derived from LET data show a complex pattern within the upper crust which cannot be correlated with geological structures as derived from reflection seismics and are thus not considered in this study. Similarly, contours at the $v_{P}>7 \mathrm{~km} \mathrm{~s}^{-1}$ located in the lithospheric mantle also exhibit a complex pattern that cannot be interpreted and thus are also not considered for this study. However, the $v_{P}=7 \mathrm{~km} \mathrm{~s}^{-1}$ contour derived from LET data follows closely the Moho determined from reprocessed CSS data as discussed by Diehl et al. (2009) and Wagner, Kissling \& Husen (2012).

In the Western Alps (Fig. 8a), the Conrad Discontinuity between the upper and lower European crust has a wavy shape, whereas the underlying Moho is more linear except for the southernmost segment. This contrast indicates that the lower European crust has been substantially deformed. A direct linkage between the shape of the Conrad Discontinuity and the structure displayed by the top surface of the crystalline basement is not possible, suggesting an independent deformation between lower and upper crust. Considering the resolution of the LET data it remains open if the antiform south of Belledonne is of a thrust nature or a pure fold. On the Adriatic side, the mantle lithosphere rises to a shallow level and the overlying Adriatic lower crust almost reaches the Earth's surface (in fact it is exposed in the Ivrea Zone $15 \mathrm{~km}$ to the NE of the cross-section). The entire shape of the lower Adriatic crust clearly shows a thick-skinned tectonic style. 


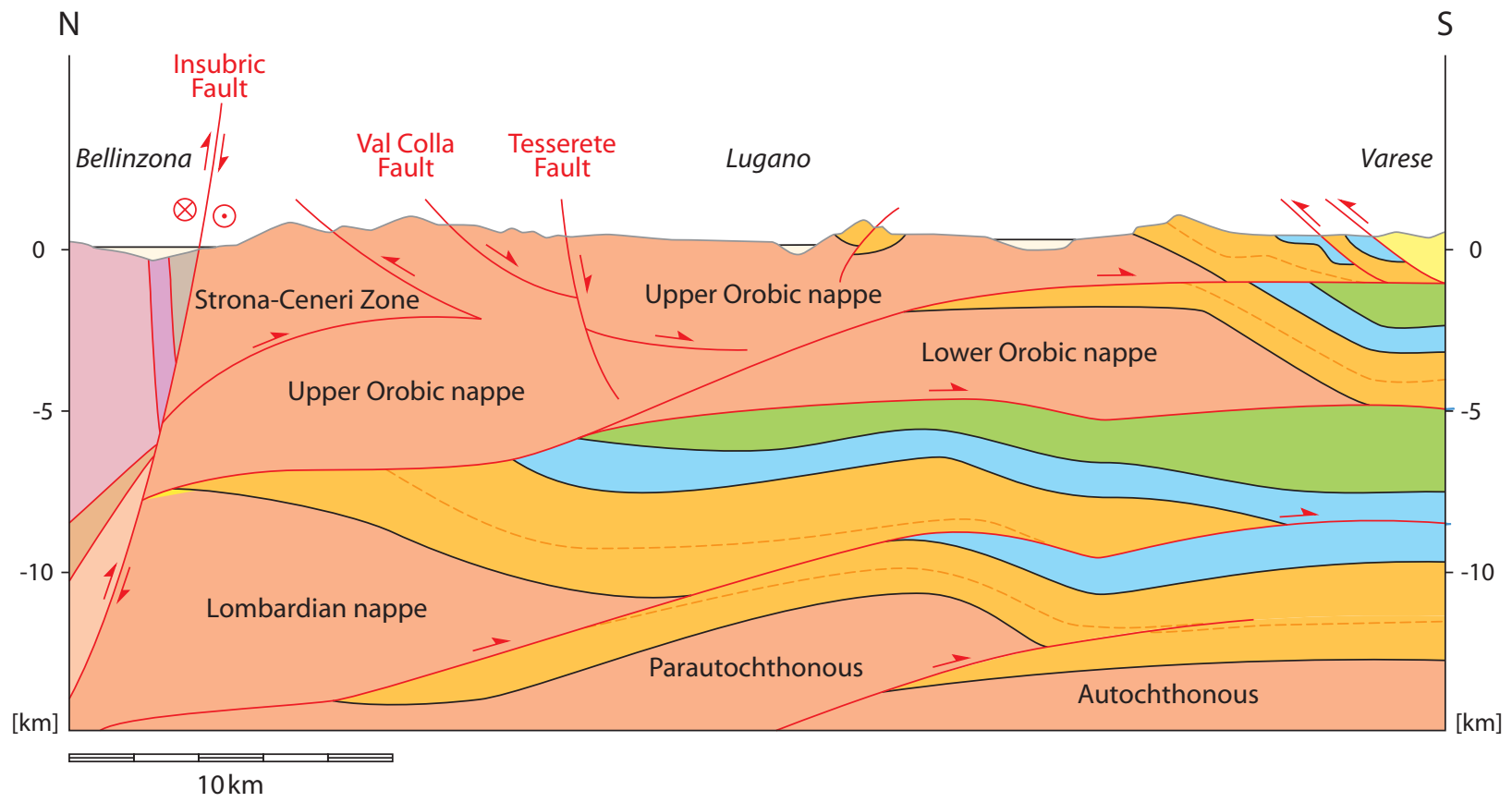

Southern Steep Belt

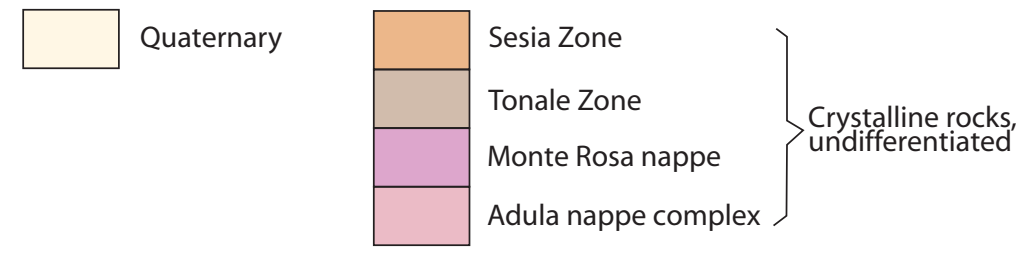

Strike-slip along Insubric Fault:

Q motion away from observer

$\odot$ motion towards observer
Southalpine nappe system

\begin{tabular}{|c|}
\hline Cenozoic (Gonfolite Lombarda) \\
\hline Cretaceous \\
\hline Jurassic \\
\hline Triassic \\
\hline Middle Triassic (Raibl Formation) \\
\hline Crystalline rocks, undifferentiated \\
\hline Lower crust (Ivrea Zone) \\
\hline
\end{tabular}

Figure 7. Cross-section through the Southalpine Orobic nappes in southern Switzerland (modified from Schumacher, 1997). See text for discussion. Trace of cross-section is given in Figure 2.

In the Central Alps (Fig. 8b), the European Moho dips more steeply to the southeast beneath the Adriatic Moho. The gap between the two Mohos is real, but the continuation of the European Moho beneath the gap is not supported by any data (and thus dashed in Fig. 8b). Interestingly there are two upper crustal units (Aar and Gotthard massifs beneath and south of Chur, respectively) that should likely have lower crustal equivalents, which are expected in the Moho gap and its extension to the southeast at depths in excess of $50 \mathrm{~km}$. It could be argued that this lower crust is metamorphosed and that the resulting higher density and $v_{P}$ velocities would thus render it undistinguishable from mantle lithosphere by geophysical methods. The depth of the thrust fault on which the Aar massif was detached from its lower crust was determined by balancing the bed length of the top of basement and the area of structural relief (Pfiffner \& Hitz, 1997). This estimate yields a depth of $12 \mathrm{~km}$ beneath the basement top, which makes it plausible to connect the detachment to the plate boundary at depth as shown in Figure 8b.

Contrary to the European crust, the Adriatic crust shows an intricate pattern of deformation, with the Con- rad Discontinuity forming two succinct highs beneath Chiavenna and Bergamo. Again it remains speculative if these highs represent fold or thrust structures, and a structural linkage between these two and the shape of the top of the crystalline basement is not possible.

An alternative interpretation of this cross-section is given in Rosenberg \& Kissling (2013). The main difference between the two interpretations lies in the structure of the lower crust of the European and Adriatic plates. Rosenberg \& Kissling (2013) preferred a smooth top for the lower crust, following the $v_{P}=$ $6.5 \mathrm{~km} \mathrm{~s}^{-1}$ contour rather loosely, whereas in Figure $8 \mathrm{~b}$ the top of the lower crust follows this contour strictly. As a consequence, the tip of the Adriatic lower crust in Figure $8 \mathrm{~b}$ is shown as being thickened, its volume balancing the volume of the upper crust that is thickened by thrust faults. Rosenberg \& Kissling (2013) showed the European lower crust as being thickened beneath the tip of the Adriatic lower crust. In both interpretations there is a disharmony between upper and lower crust, suggesting a decoupling at the middle crustal level.

Both cross-sections, Figure 8a, b, suggest that the Adriatic lower crust has been indented into the 
(a)
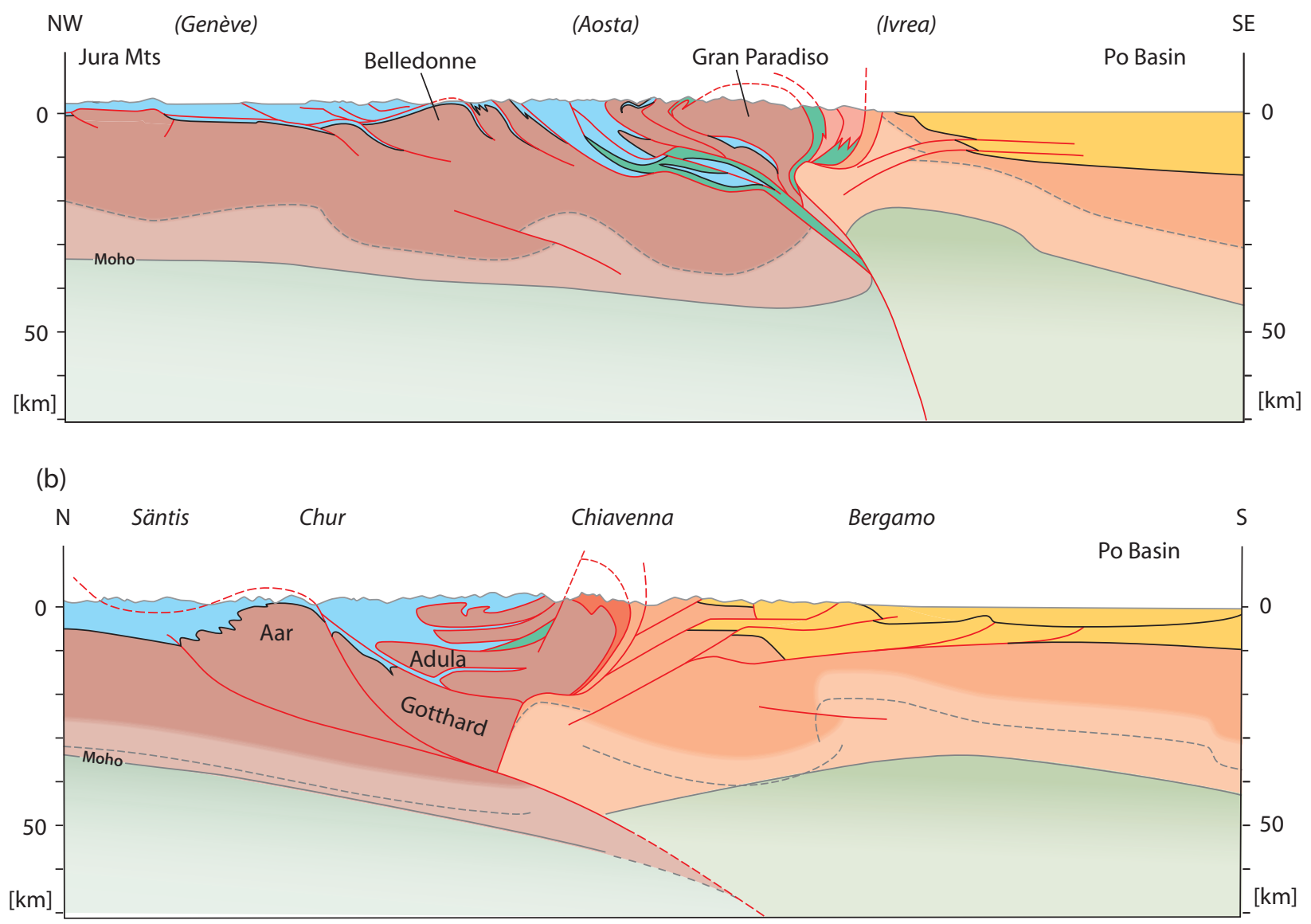

$100 \mathrm{~km}$

\section{European continental margin}

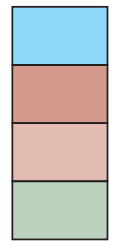

Mesozoic-Cenozoic strata

European upper crust

European lower crust

Lithospheric mantle
Oligocene Intrusives

Oceanic crust

\section{Adriatic continental margin}

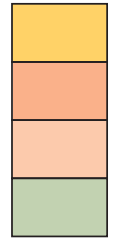

Mesozoic-Cenozoic strata

Adriatic upper crust

Adriatic lower crust

Lithospheric mantle

Figure 8. Cross-sections showing crustal structure of the Alps. See text for discussion. (a) Western Alps. (b) Central Alps. Traces of cross-sections are given in Figure 2.

European crust, thereby uplifting the Penninic basement units. The nature of the crustal structure clearly indicates a thick-skinned tectonic style, where the lower and upper crust deformed somewhat independently. A link from shallow upper crustal structures (for example thrust faults) to a deeper lower crustal level cannot be established. This suggests that thrust faults involving crystalline basement level off in the middle crust and pass into broad shear zones.

\section{Kinematic succession of nappe formation}

The various Alpine nappes discussed in Section 2 and the crustal structure described in Section 3 formed separately in time, location and depth. In order to display the kinematic evolution of these structures, a set of restored cross-sections through the Central Alps will be presented. The cross-sections rely on an original set of restored sections presented by Schmid et al. (1996) and Schmid, Pfiffner \& Schreurs (1997); these works also give a detailed discussion on the dating of the various deformation phases involved in creating the Alpine nappe stack. A summary of the structural evolution of the Alps in these cross-sections accompanied by an orogenic time table is presented in Pfiffner (2014).

Apart from structural data on folding and thrusting within the Alpine nappe pile, a retrodeformation also needs petrologic data, which indicate at which pressure and temperature conditions these structures formed. As examples, $p-T-t$ paths obtained for the Adula and 


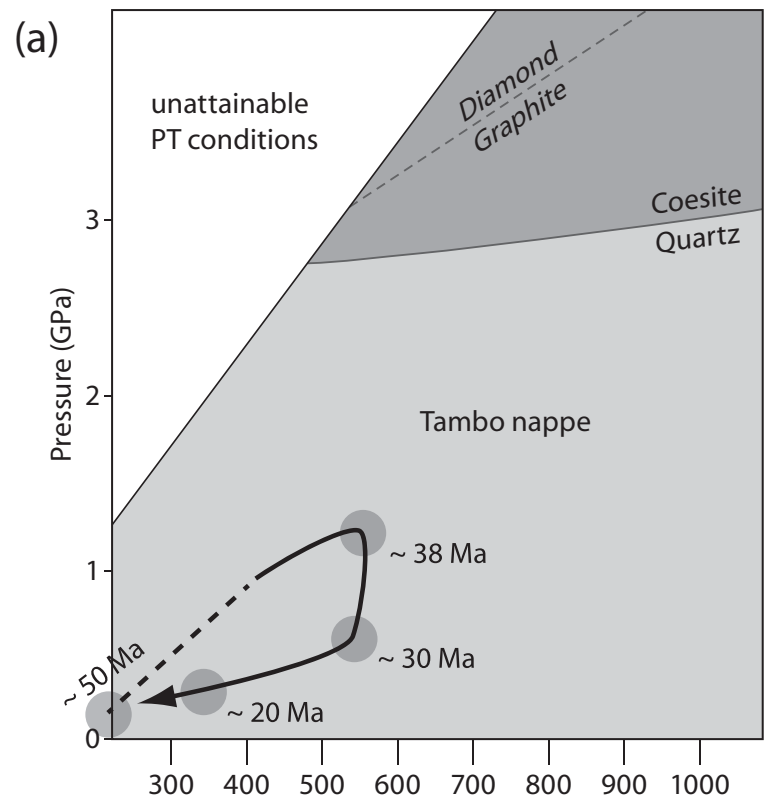

(b)

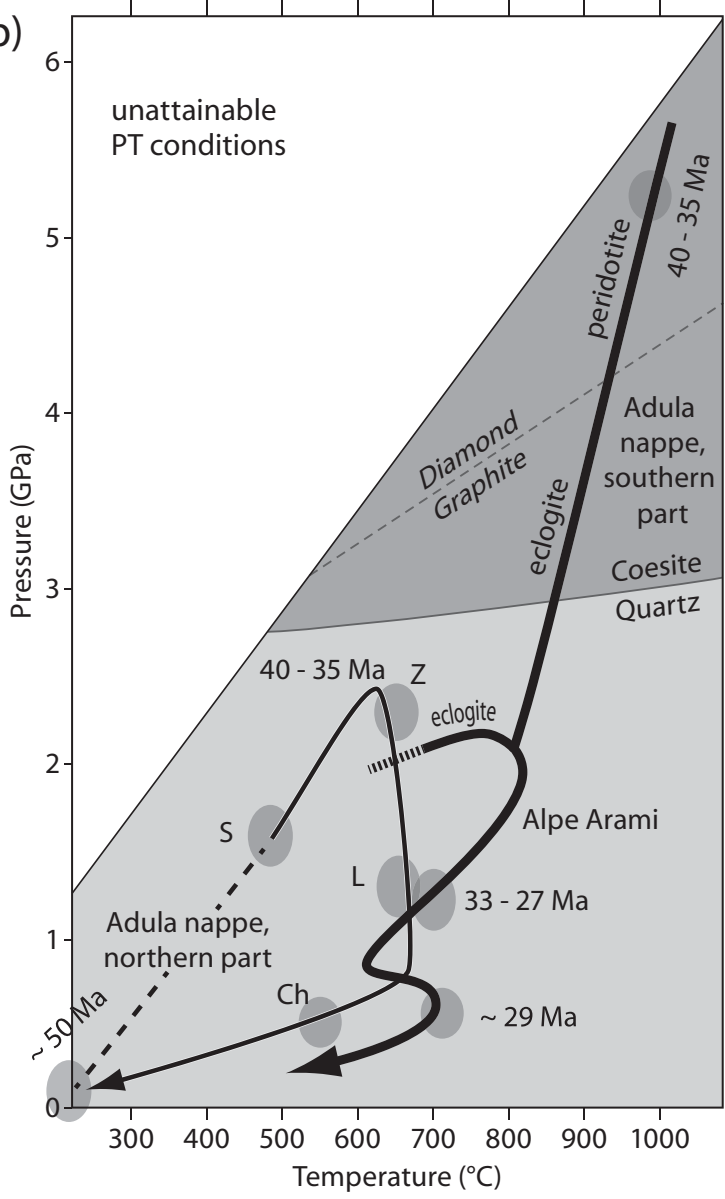

Figure 9. $p-T-t$ paths determined for Penninic basement nappes of the Central Alps. (a) Tambo nappe. (b) Adula nappe. S, Z, L and $\mathrm{Ch}$ refer to deformation phases, where $\mathrm{Z}$ (Zapport) corresponds to a phase of nappe stacking.

Tambo nappes (both discussed in Section 2) are shown in Figure 9. They are based on Marquer et al. (1994), Frey \& Ferreiro Mählmann (1999) and Nagel et al. (2002). In both cases, the timing of the $p-T$ loops is relatively well constrained. Comparison of the two graphs (a) and (b) reveals that although tectonic burial for both nappes starts at around $50 \mathrm{Ma}$, the Adula nappe was buried much deeper compared to the Tambo nappe. In addition, within the Adula nappe the southern part was buried much deeper than the northern part. Following Petrini \& Podladchikov (2000) and Mancktelow (2008), the pressures determined from metamorphic mineral assemblages were converted to depths by allowing a contribution of tectonic overpressure of the order of $50 \%$ to these pressures. As discussed by Pleuger \& Podladchikov (2014), overpressures are likely to have varied in time and space. The $50 \%$ used in the reconstruction is thus a first-order approximation only.

The retrodeformed (restored) cross-sections constructed for time slices within the Cenozoic are shown in Figure 10. These sections are based on the original sections shown in Schmid et al. (1996) and Schmid, Pfiffner \& Schreurs (1997) but have been substantially modified. They cover a total of at least $c .700 \mathrm{~km}$ of convergence between the European and Adriatic margins. The convergence numbers indicated are taken from Schmid et al. (1996) and Schmid, Pfiffner \& Schreurs (1997).

On a lithospheric scale the cross-sections reveal the rollback of the European plate from Paleocene time up into Oligocene time. The hinge of the plate is located south of the Briançon microcontinent at $65 \mathrm{Ma}$ (Fig. 10a), in the Valais Basin at $50 \mathrm{Ma}$, south of Simano at $40 \mathrm{Ma}$ and south of Lucomagno at $32 \mathrm{Ma}$. The rollback velocity may be estimated at $20 \mathrm{~mm} \mathrm{a}^{-1}$ in Paleocene time and $10 \mathrm{~mm} \mathrm{a}^{-1}$ in Eocene time. These numbers compare to the convergence rates determined by Schmid et al. (1996) and the progradation rates of the foreland bulge reported by Kempf \& Pfiffner (2004). From Oligocene time on, important dextral strike-slip occurred along the Insubric fault. This brought a different piece of the leading edge of the Adriatic plate into the cross-section considered here.

Figure 10a shows the situation at $65 \mathrm{Ma}$. At this stage the Piemont Ocean had been subducted and the Briançon microcontinent enters the subduction zone. The $200 \mathrm{~km}$ of convergence accomplished so far is an absolute minimum estimate. The Valais Basin that had formed in Jurassic and mainly Cretaceous times (Steinmann, 1994) had a basement consisting of thinned continental crust and new oceanic crust (Steinmann \& Stille, 1999). This substratum was to become the future Adula nappe.

By $50 \mathrm{Ma}$, after an additional convergence of about $200 \mathrm{~km}$, the Briançon microcontinent was subducted, but its Mesozoic sedimentary cover had already been detached (Avers Phase of Milnes \& Schmutz, 1978) and remained at a shallow level, marking the onset of thin-skinned tectonics. The basement of the Valais Basin was also subducted; its Mesozoic cover had been detached and remained at a more shallow level. The youngest sediments deposited in the Valais Basin are Early Eocene in age and were of a flysch character (Prättigau Flysch; Nänny, 1948); they were accumulated in the trench where active thrust faults broke the surface. The southern part of the continental basement, 

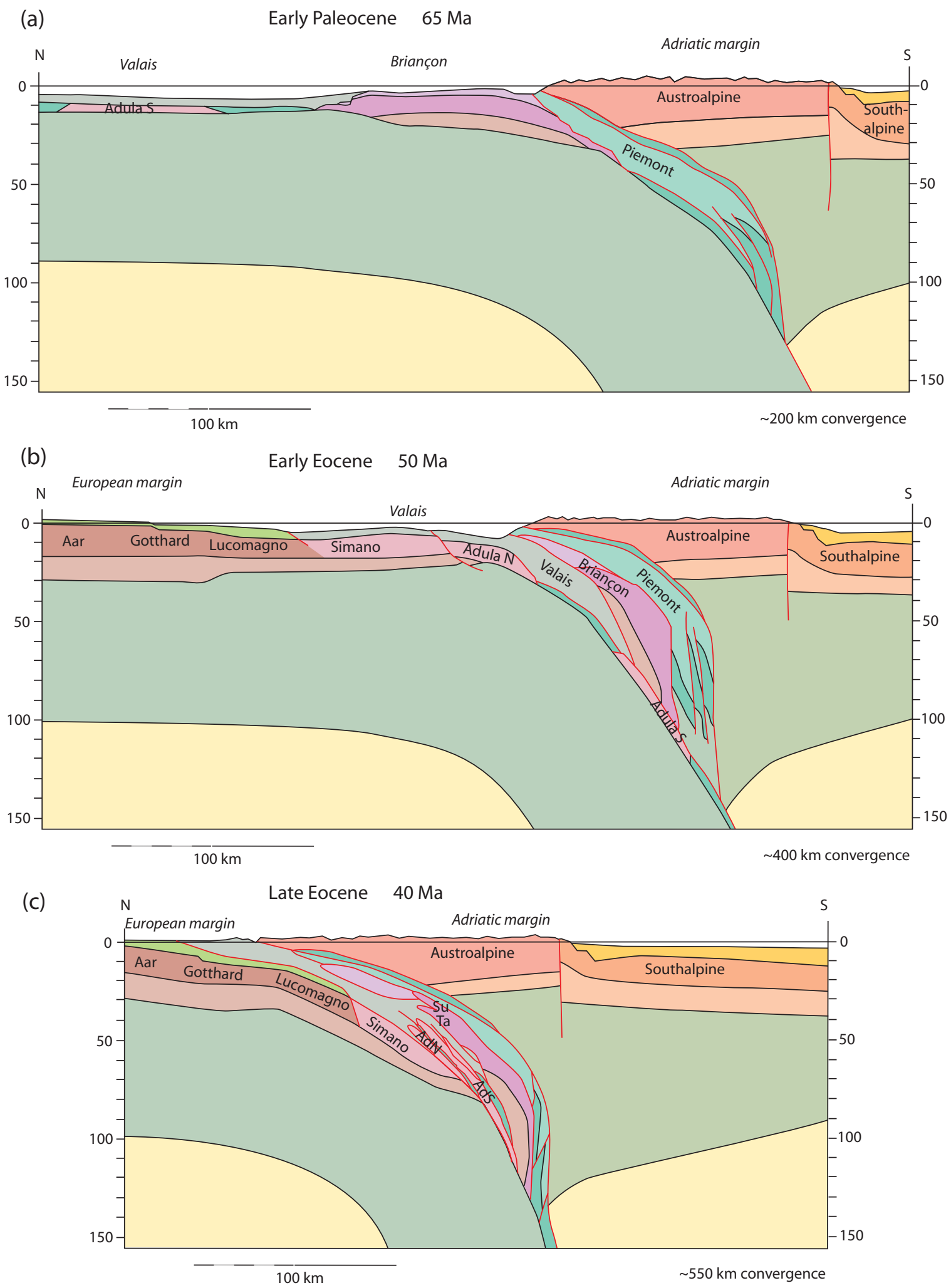

Figure 10. Restored cross-section through the Central Alps of eastern Switzerland. See text for discussion. (a) Piemont ocean subducted, entrance of Briançon microcontinent. (b) Briançon cover detached. Valais basement (Adula) subducted, cover detached. (c) Stacking and expulsion of basement nappes (Suretta, Tambo, Adula). (d) Back-folding and thrusting along Insubric fault, Helvetic cover detached. (e) Further back-folding and thrusting along Insubric fault, indentation of Adriatic plate, basement of Gotthard and Aar massifs thrust and updomed. Su -Suretta; Ta - Tambo; AsS - Adula south; AsN - Adula north; Si - Simano; Lu - Lucomagno. 

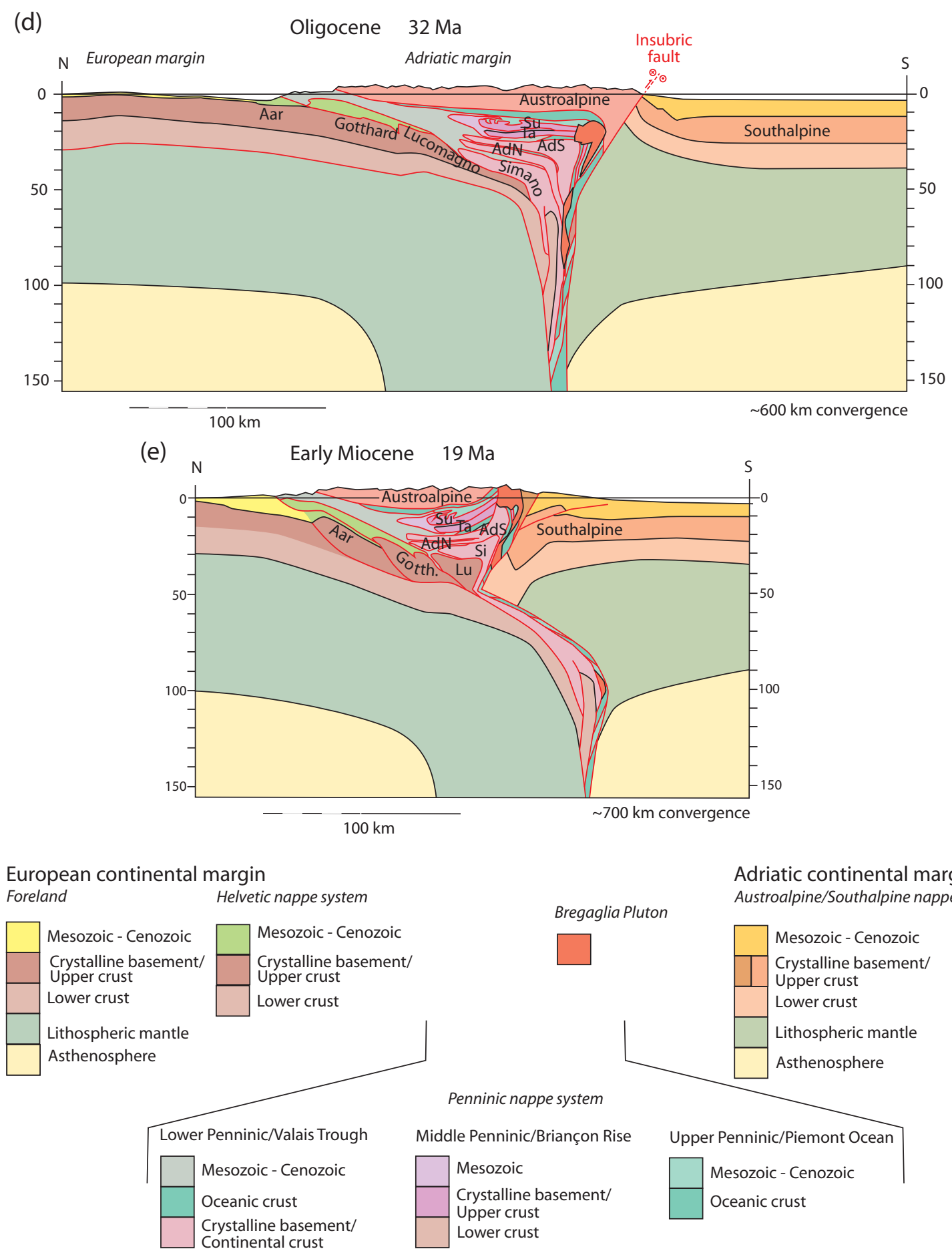

Figure 10. Continued.

Adula $\mathrm{S}$ in Figure 10b, had reached a depth of around $100 \mathrm{~km}$ and was eclogitized, whereas the northern part, Adula $\mathrm{N}$ in Figure 10b, lagged behind, which explains the lesser degree of metamorphism this part acquired (cf. Fig. 9b).

Figure 10c depicts the subduction geometry at $40 \mathrm{Ma}$, after another $150 \mathrm{~km}$ of convergence. By this time the European continental margin entered the contact zone and triggered the onset of continent-continent collision (Schmid et al. 1996; Schmid, Pfiffner \& Schreurs, 1997). At this time rapid decompression set in in the Tambo and Adula nappes (cf. Fig. 9a, b). This is explained by a detachment and rapid upward motion of the upper crust of the Briançon microcontinent. The upper crust was thereby shortened and stacked (Ferrera Phase of Milnes \& Schmutz, 1978) to form the Tambo and Suretta nappes (Ta and Su in Figure 10c; see Scheiber, Pfiffner \& Schreurs, 2012). These nappes were subsequently jammed into their original but detached sedimentary cover (Schams nappe), and overprinted its earlier formed thin-skinned style (NiemetBeverin Phase of Schreurs, 1995). In the case of the 
Adula nappe, the various pieces of continental and oceanic crust were stacked (Zapport phase, Z, in Fig. 9b) and expelled upwards. Buoyant rise may have contributed to this but the exact nature is still a matter of debate (see discussion in Nagel et al. 2002). Engi, Berger \& Roselle (2001) described the formation of this nappe stack within the subduction zone and proposed the term 'tectonic accretion channel' to explain its nature. In any case, this stack is also an example of basement-involved thin-skinned tectonics, and its emplacement into the higher units also deformed the earlier formed structures within the detached cover sediments.

By $32 \mathrm{Ma}$ and another $50 \mathrm{~km}$ of convergence the geometry of the plate boundary had profoundly changed (Fig. 10d). Slab break-off of the leading edge of the European plate (not shown in Fig. 10) and the further advance of the European continental crust caused a buoyancy effect, which triggered vertical escape of the Penninic nappe stack. This was accomplished by the formation of a major S-vergent back-fold and steep back-thrusting along the Insubric fault. The latter was simultaneously active by dextral strike-slip. Melts that formed as a consequence of upwelling following slab break-off (von Blanckenburg \& Davis, 1995) were rising along the steep zone bordering the Insubric fault and intruded the Adula, Tambo and Suretta nappes (Bregaglia intrusion).

In the north, the sedimentary covers of the Lucomagno and Gotthard basement blocks were detached at about this time and moved northwards as Helvetic nappes (Calanda Phase of Pfiffner, 1986) much in the style of thin-skinned tectonics. Still further north, the Northhelvetic Flysch Basin was being filled on top of the future Aar massif.

As shown in Figure 10e, in Miocene time backfolding and back-thrusting north of and along the Insubric fault continued and now also included Simano and Lucomagno ( $\mathrm{Si}$ and $\mathrm{Lu}$ in Fig. 10e). Erosion accompanied (and facilitated) back-folding and backthrusting such that by $19 \mathrm{Ma}$ the Bregaglia intrusion was exhumed and shed pebbles into the Po Basin (Giger $\&$ Hurford, 1989).

In the north, the Helvetic nappes had travelled further north in a thin-skinned style and the Gotthard massif started to overthrust the Aar massif (basement-involved thin-skinned tectonics). The latter started updoming thereby deforming the now inactive basal thrust of the overlying Helvetic nappes (Pfiffner, 1986). Molasse sedimentation prevailed in the Northalpine foreland basin.

Sedimentation also continued in the Po Basin to the south. The margin of the Adriatic plate now present in the cross-section considered here was shortened in a thick-skinned manner. As discussed in Schmid \& Kissling (2000), the Adriatic plate underwent an anticlockwise rotation concurrent with the dextral strikeslip along the Insubric fault. As shown in Figure 10e, it is interpreted that this rotation indented the leading edge of the Adriatic plate into the European plate and that the Adriatic plate overrode the subducted European slab.

The overridden European slab likely had remnants of lower and maybe even upper continental crust that were still attached to the mantle lithosphere. Considering the depth range, one would expect that these crustal lenses were eclogitized in the process and thus not detectable by geophysical methods. It is these units that might be expected in the Moho gap and its southern extension discussed in conjunction with Figure $8 b$.

The kinematic sequence of nappe formation in this transect clearly shows that as the European margin entered the subduction zone, first the sedimentary cover was detached. This cover remained at a shallow depth whereas the crystalline basement was subducted to greater depths. Once there, the basement units were detached from their substratum and stacked into a nappe pile, which then moved upwards aided by buoyancy and erosion at the surface. The upward movement deformed the units at shallower depth and triggered post-nappe folding. The mechanism of thin-skinned frontal accretion followed by thick-skinned basal accretion has been analysed by numerical modelling by Selzer, Buiter $\&$ Pfiffner (2008). The model study suggested that erosion enhances the formation of thick-skinned-type basement nappes at depth, while sedimentation at the front of the orogen favours the formation of thin-skinned-type nappes.

\section{Mechanical implications}

Structural analyses clearly show that, generally speaking, in the Alps the sedimentary cover was detached in an early stage of nappe formation and was followed by the stacking of basement nappes. Considering the Alpine cover nappes, detachment occurred mainly along Triassic evaporites, which are present in many instances. Such a detachment is possible at very low temperatures of less than $150^{\circ} \mathrm{C}$, as was the case, for example, in the Jura Mountains.

In the case of crystalline basement nappes, the presence of Permo-Carboniferous and Mesozoic basins embedded in gneissic and granitic basement played some role during nappe formation. Such basins are associated with steep synsedimentary normal faults bounding them. It seems that the lateral heterogeneity present at the margins of these basins controlled the initiation of thrust faults. Examples of this behaviour include the Glarus Verrucano in the Glarus nappe (Pfiffner, 2014) and the Rofna Porphyry complex in the Suretta nappe (Scheiber, Pfiffner \& Schreurs, 2012), both of which are Permian structures. Bellahsen et al. (2012) discussed the localization of basement deformation by Mesozoic syn-rift basins that led to thick-skinned tectonics in the Western Alps. Their conclusion is that the Jurassic normal faults were not directly reactivated but caused shear zones tens or hundreds of metres thick that extend into the basement and led to fold-like structures at the cover-basement interface. 
In the absence of such syn-rift basins, basement nappes are typically 1 to $5 \mathrm{~km}$ thick and tens of kilometres long in the direction of transport, suggesting that detachment occurred within the upper crust and along a horizontal or shallow-dipping horizon. The determination of the depth of detachment requires the retrodeformation of the Alpine overprint. For the Suretta nappe (Fig. 4a) Scheiber, Pfiffner \& Schreurs (2012) reported a depth of $5 \mathrm{~km}$ for the detachment horizon at the time of its initiation. In the Tambo nappe (Fig. 4b) the estimate for this depth is $8 \mathrm{~km}$ (Mayerat-Demarne, 1994), and in the Bernhard nappe complex (Scheiber, Pfiffner \& Schreurs, 2013) about $10 \mathrm{~km}$.

In the case of the external basement massifs, the reflection seismic data of NRP20 (Pfiffner, Sahli \& Stäuble, 1997) indicate that in the Central Alps, detachment faults reach down to depths of more than $10 \mathrm{~km}$ beneath the top-basement contact; however, a levelling off of the faults at depth cannot be derived from these data. In the Western Alps, Bellahsen et al. (2014) proposed that the thrust faults at the front of the external massifs reach down to 15 or $20 \mathrm{~km}$ depth; but here too, an interpretation of the geometry at greater depth is not presented. Lacombe \& Mouthereau (2002) proposed that a thermally weakened middle crust could be responsible for the detachment and caused the decoupling of lower and upper crust. Considering the relatively small displacements along individual thrust faults related to the external basement massifs (around $5 \mathrm{~km}$, in a few instances $10 \mathrm{~km}$ ), it is well possible that these faults die out at greater depth owing to differential stretching in the footwall and hanging wall parallel to the thrust faults compensating for the displacement (Pfiffner, 1985). For example, a displacement of $10 \mathrm{~km}$ can die out after $1 \mathrm{~km}$ distance along the fault if a differential stretch of $10 \%$ is assumed. Differential stretches may be envisaged if a fault gives way to a broad shear zone in the ductile regime.

Regarding the depth of the initiation of detachments, it is interesting to consider experimental data on rock strengths. Figure 11 shows a compilation of experimental data of plastic strengths for typical rock types involved in nappe formation after Suppe (1984). The data are normalized to strain rates of $10^{-13} \mathrm{~s}^{-1}$, which correspond to typical strain rates determined in orogens (Pfiffner \& Ramsay, 1982). Brittle strength curves are given for hydrostatic pressure and for overpressure after Suppe (2014). In addition, the strength reduction caused by the breakdown of feldspar as a load-bearing phase to phyllonite based on O'Hara (2007) is also shown.

If a small volume of crystalline basement topped by sediments (represented by dark grey rectangles in Fig. 11) is considered, which is then buried as would be typical for orogenic processes, temperature and differential stress would increase with time. The path this volume of rocks would take could follow any of the arrows shown in Figure 11, depending on the local conditions of stress and the reigning geothermal gradient. Except for the unlikely horizontal path corresponding to increase in differential stress without temperature rise, the rock volume under consideration would hit the strength curve of anhydrite first, and in a much later stage reach the strength curves of limestone or quartz. Thus, it is to be expected that evaporites (anhydrite) trigger detachment in an early stage of burial by orogenesis. The temperatures required for strength reduction of quartz or the breakdown of feldspar to produce phyllonites are higher and thus reached much later at greater depths in a subduction regime. This explains why in Alpine-type nappes, thin-skinned tectonics precede basement-involved thin-skinned and thick-skinned tectonics.

The fact that basement nappes are thin slabs of regular thickness may reflect that the detachment followed a pre-existing zone of weakness or, alternatively, that strength reduction owing to higher temperatures occurred at a certain depth beneath the basement-cover contact. In the case of the Tambo nappe, the rocks at the detachment horizon were at more than $400{ }^{\circ} \mathrm{C}$ (see Fig. 9a) and thus could have allowed a weak zone to develop $8 \mathrm{~km}$ beneath the basement-cover contact, which then eventually developed into a detachment horizon. This implies that the palaeogeotherms remained more or less parallel to the basement-cover contact. Unfortunately, the rocks at the very base of the Tambo nappe are not exposed, rendering the study of a potential strain gradient impossible. Baudin, Marquer \& Persoz (1993) reported a heterogeneous distribution of ductile deformation within the Tambo nappe with shearing being more pronounced at the top of the nappe.

In contrast, the Suretta nappe displays a quartzofeldspathic mylonite up to $100 \mathrm{~m}$ thick at its base (Scheiber, Pfiffner \& Schreurs, 2012). The presence of ribbon quartz and ribbon feldspar point to elevated temperatures and, associated, low strength of the porphyritic protolith. As discussed by Scheiber, Pfiffner \& Schreurs (2012), the basal detachment of the Suretta nappe was also controlled by the presence and shape of the Rofna Porphyry complex: the basal detachment followed the base of the intrusive complex, the frontal ramp its lateral contact.

Carry et al. (2009) modelled the effect of pressure and temperature increase in a continental margin as it is being subducted. In their model, the pressure increase with depth during subduction is followed by temperature increases owing to heating from the overlying hot lithosphere. As a consequence the strength of the margin first increases and then decreases as temperatures rise. The strength gradients in the model suggest that stacking of thin crustal slices becomes possible once the subducting slab has reached a certain depth, which itself depends on subduction dip angle, crustal rheology, heat flux and subduction velocity (op. cit.).

A different mechanism for weakening crystalline rocks is the transformation of the load-bearing feldspar by mechanically weaker phyllosilicates (Jefferies et al. 2005; O'Hara, 2007). In this mechanism lowtemperature cataclasis provides the permeability for the passage of fluids, which in turn aid the breakdown 


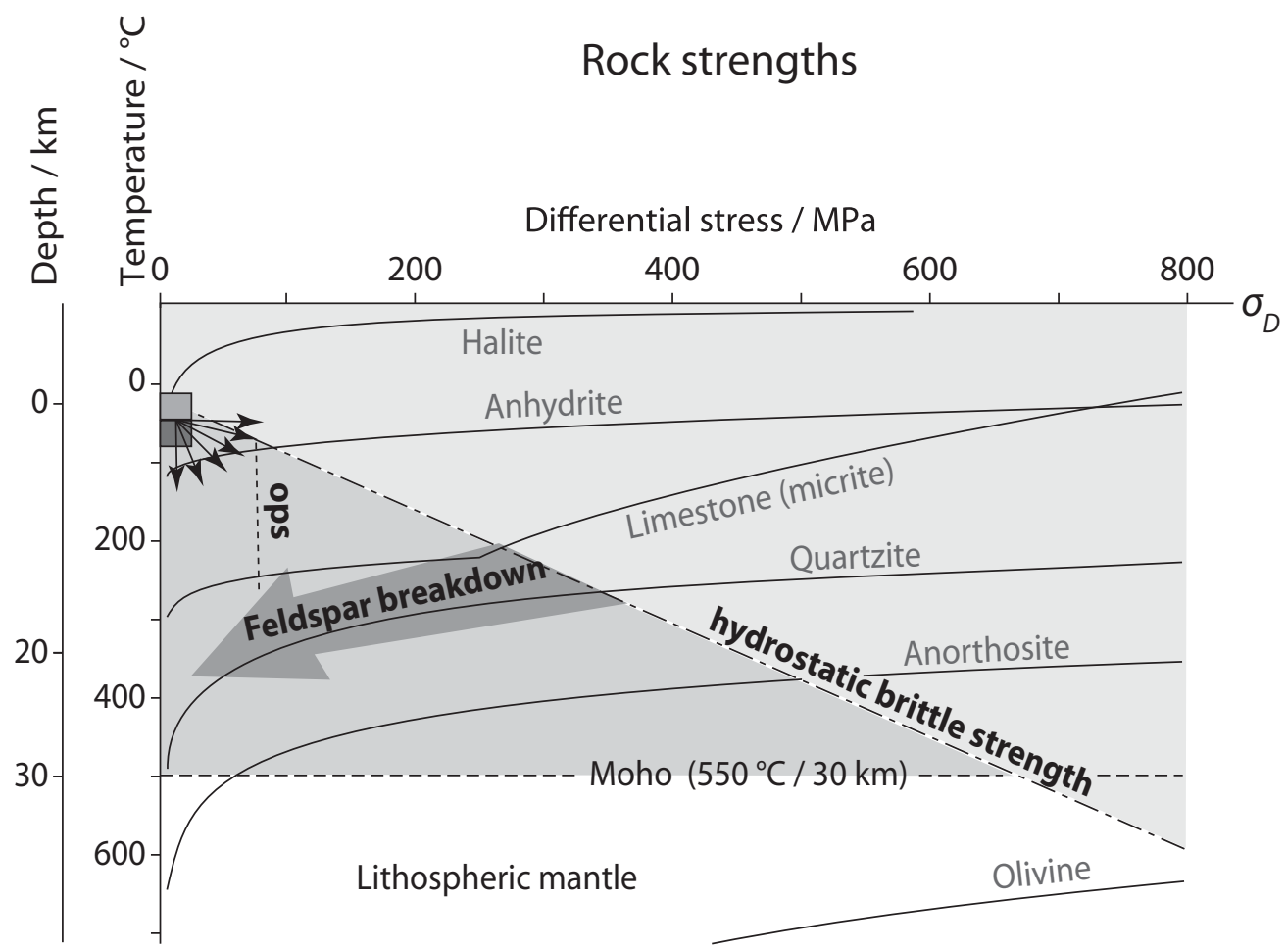

Figure 11. Experimentally determined strengths of typical rocks encountered in continental crust. Arrows indicate potential paths taken by an uppermost crustal block made of crystalline basement and cover sediments. Strength curve of anhydrite is reached long before strength curve of quartzite. Phyllonite production by breakdown of feldspar may occur at temperatures comparable to or lower than ductile deformation of quartz. ops - overpressured brittle strength.

of feldspar and the formation of phyllonite. The breakdown of feldspar and the associated strength reduction of the rocks can occur at temperatures between 200 and $400^{\circ} \mathrm{C}$ (O'Hara, 2007), and thus prior to the conditions for the weakening of quartz (see Fig. 11). Such a scenario for strength reduction has been documented for the Ecrins massif in the Western Alps by Bellanger et al. (2014) and is also plausible in the external basement massifs (Aar, Aiguilles Rouges, Mont Blanc, Belledonne) where the degree of metamorphism attained and the temperatures operative during thrusting are modest in comparison to the subducted basement nappes of the Penninic nappe system. Lacombe $\&$ Mouthereau (2002) suspected that thermal weakening within the middle crust could represent a detachment horizon in foreland thrust belts and contribute to the formation of antiforms like the external basement massifs in the Alps. Nevertheless, as pointed out by Bellahsen et al. (2014), the internal structures of these external massifs vary along strike, a change that these authors attributed to the impact of Mesozoic rifting. They attributed the higher shortening observed in the Central Alps (Aar, Mont Blanc - Aiguilles Rouges) compared to the Western Alps (Belledonne) to a more strongly thinned crust in the Central Alps that was more deeply buried during collision, heated up, and thereby weakened and more strongly deformed. In contrast, the buoyant thicker crust of the Belledonne massif in the Western Alps remained at a shallower level, thus cooler and consequently experienced less pervasive deformation.
Comparing the external massifs and the Penninic basement nappes it becomes clear that the latter were buried much deeper and the crust consequently weakened. In the case of the Tambo, Suretta and Bernhard nappe complex, nappes derived from the Briançon microcontinent, the upper crust was detached from the lower crust and expelled from depth while the lower crust was subducted (Schmid et al. 1996). In the case of the Adula nappe, Mesozoic rifting led to the formation of extensional allochthons which were sheared off their lower crust. The stacking of these allochthons occurred at temperatures in excess of $400^{\circ} \mathrm{C}$ (Fig. 9b). Thrusting thus affected a weak crust and may have followed shallow-dipping parts of Jurassic normal faults. Such a scenario is also envisaged in the case of the Austroalpine nappes, where Mohn et al. (2011) discussed the importance of rift-related structures on the formation of Alpine nappe structures, namely the partial reactivation of low-angle Jurassic faults. These hyper-extended situations result in the formation of very thin basement nappes owing to their Mesozoic history. Stacking of these basement nappes results in an overall geometry resembling thin-skinned cover nappes in size.

\section{Conclusions}

In the Helvetic-Dauphinois and Penninic nappe systems of the Alps, detachment of cover sediments by thin-skinned tectonics occurred early in the orogenesis. It was followed by basement-involved thin-skinned 
tectonics in the Penninic nappe system. In the course of this, the earlier formed thrust faults were intricately folded ('post-nappe folding'). Thick-skinned tectonics involving the entire upper crust took place in the latest phase of collision in the Helvetic-Dauphinois nappe system.

The presence of evaporite formations was responsible for the detachment of cover nappes in many cases. Fluid overpressures may have played a role in shaly or marly formations.

Basement-involved thin-skinned tectonics can be attributed to originally thinned continental crust that was subducted to greater depths. In these nappes, strength reduction by rising high temperatures led to ductile deformation that controlled detachment of thin upper crustal pieces. Pre-existing mechanical discontinuities (e.g. Permo-Carboniferous magmatic complexes or basins) acted as a focus for the development of detachment and fault ramps.

The thick-skinned tectonic style in the external basement massifs, which occurred late in the collision stage, involves thrusts reaching $12 \mathrm{~km}$ down into the middle crust. A detachment at this level could have been controlled by the breakdown of feldspar and formation of phyllonites. Reflection seismics, however, do not show a phyllonite layer of sufficient thickness to be detectable seismically. Alternatively, a gradual decrease of the displacement along these thrust faults accommodated by differential stretching of the hanging wall and/or footwall rocks may be responsible for the disappearance of these thrust faults.

The crustal-scale disharmony between upper and lower crust requires some ductile or semi-ductile deformation at the middle crustal level. The wavy nature of the top of the lower crust cannot be correlated with the structure of the upper crust related to thick-skinned tectonics.

Acknowledgements. I would like to thank Alfons Berger for the many discussions on the structure of the Adula nappe and Edi Kissling for his advice on how to interpret the earthquake tomography data. The detailed comments by C. Rosenberg, O. Lacombe and an anonymous reviewer greatly improved the quality of the manuscript.

\section{References}

Ansorge, J., Blundell, D. \& Mueller, S. 1992. Europe's lithosphere - seismic structure. In A Continent Revealed - The European Geotraverse (eds D. Blundell, R. Freeman \& S. Mueller), pp. 33-69. Cambridge: Cambridge University Press.

ARGAND, E. 1916. Sur l'arc des Alpes Occidentales. Eclogae Geologicae Helvetiae 14, 145-91.

Baudin, T., Marquer, D. \& Persoz, F. 1993. Basementcover relationships in the Tambo nappe (Central Alps, Switzerland): geometry, structure and kinematics. Journal of Structural Geology 15, 543-53.

Bellahsen, N., Jolivet, L., Lacombe, O., Bellanger, M., Boutoux, A., Garcia, S., Mouthereau, F., Le Pourhiet, L. \& GumiauX, C. 2012. Mechanisms of margin inversion in the external Western Alps: im- plications for crustal rheology. Tectonophysics 560-61, 62-83.

Bellahsen, N., Mouthereau, F., Boutoux, A., Bellanger, M., LACOMBe, O., JOLIVET, L. \& Rolland, Y. 2014. Collision kinematics in the western external Alps. Tectonics 33, 1055-88.

Bellanger, M., Bellahsen, N., Jolivet, L., Baudin, T., Augier, R. \& BoutouX, A. 2014. Basement shear zones development and shortening kinematics in the Ecrins Massif, Western Alps. Tectonics 33, 84-111.

Berger, A. \& Mercolli, I. 2006. Tectonic and Petrographic Map of the Central Lepontine Alps 1:100,000, Map Sheet 43 Sopra Ceneri. Geological Special Map No. 127. Swiss Geological Survey/swisstopo.

Boutoux, A., Bellahsen, N., Lacombe, O., Verlaguet, A. \& MOUTHEREAU, F. 2014. Inversion of pre-orogenic extensional basins in the external Western Alps: structure, microstructures and restoration. Journal of Structural Geology 60, 13-29.

BURKHARD, M. 1988. L'Helvétique de la bordure occidentale du massif de l'Aar (evolution tectonique et métamorphique. Eclogae Geologicae Helvetiae 81, 63-124.

BurkHARD, M. \& SOMMARUga, A. 1998. Evolution of the western Swiss Molasse basin: structural relations with the Alps and the Jura belt. In Cenozoic Foreland Basins of Western Europe (eds A. Mascle, C. Puigdefabregas, H. P. Luterbacher \& M. Fernandez), pp. 279-98. Geological Society of London, Special Publication no. 134.

CARrY, N., GueYdan, F., Brun, J. P. \& MARQuer, D. 2009. Mechanical decoupling of high-pressure crustal units during continental subduction. Earth and Planetary Science Letters 278, 13-25.

CAVARgna-SANI, M., EPARD, J.-L., Bussy, F. \& UlianOV, A. 2014. Basement lithostratigraphy of the Adula nappe: implications for Palaeozoic evolution and Alpine kinematics. International Journal of Earth Sciences (Geologische Rundschau) 103, 61-82.

CAVARGNA-SANI, M., EPARD, J.-L. \& STECK, A. 2014. Structure, geometry and kinematics of the northern Adula nappe (Central Alps). Swiss Journal of Geosciences 107, 135-56.

DeCELLES, P. G. 1994. Late Cretaceous-Paleocene synorogenic sedimentation and kinematic history of the Sevier thrust belt, northeast Utah and southwest Wyoming. Geological Society of America Bulletin 106, 32-56.

DeCELles, P. G. 2004. Late Jurassic to Eocene evolution of the Cordilleran thrust belt and foreland basin system, western U.S.A. American Journal of Science 304, 105-68.

Diehl, T., Husen, S., Kissling, E. \& DeichmanN, N. 2009. High-resolution 3-D $P$-wave model of the Alpine crust. Geophysical Journal International 179, 1133-47.

ELLENBERGER, F. 1952. Sur l'extension des faciès Briançonnais en Suisse, dans les Préalpes médianes et les Pennides. Eclogae Geologicae Helvetiae 45, 285-6.

ELLIOTT, D. \& JOHNSON, M. R. W. 1980. Structural evolution in the northern part of the Moine thrust belt, NW Scotland. Transactions of the Royal Society of Edinburgh: Earth Sciences 71, 69-96.

Engi, M., Berger, A. \& Roselle, G. T. 2001. Role of the tectonic accretion channel in collisional orogeny. Geology 29, 1143-6.

Escher, A., MAsson, H. \& STECK, A. 1993. Nappe geometry in the Western Swiss Alps. Journal of Structural Geology 15, 501-9.

Frey, M. \& FERreiro MäHLMANN, R. 1999. Alpine metamorphism of the Central Alps. Schweizerische Mineralogische und Petrographische Mitteilungen 79, 135-54. 
GIGER, M. \& HuRford, A. J. 1989. Tertiary intrusives of the Central Alps: their Tertiary uplift, erosion redeposition and burial in the south-alpine foreland. Eclogae Geologicae Helvetiae 82, 857-66.

Groshong, Jr, R. H., Pfiffner, O. A. \& Pringle, L. R. 1984. Strain partitioning in the Helvetic thrust belt of eastern Switzerland from the leading edge to the internal zone. Journal of Structural Geology 6, 5-18.

HÄNNI, R. \& PfIFFNER, O. A. 2014. Geologische Profile Wellenberg. Nagra Arbeitsbericht NAB 12-04. Wettingen: Nationale Genossenschaft für die Lagerung radioaktiver Abfälle.

HeIM, A. 1919, 1921, 1922. Geolgie der Schweiz, Volumes I and II $a \& b$. Leibzig: Tauchnitz. $704+1018$ pp.

HeIM, M., SChÄrer, U. \& MilnES, A. G. 1977. The nappe complex in the Tyin-Bygdin-Vang region, central southern Norway. Norsk Geologisk Tidsskrift 57, 171-8.

HITZ, L. 1996. The deep structure of the Engadine window: evidence from deep seismic data. Eclogae Geologicae Helvetiae 89, 657-75.

Jefferies, S. P., Holdsworth, R. E., WibBerley, C. A. J., Shimamoto, T., Spiers, C. J., Niemeijer, A. R. \& LLOYD, G. E. 2006. The nature and importance of phyllonite development in crustal-scale fault cores: an example from the Median Tectonic Line, Japan. Journal of Structural Geology 28, 220-35.

KEMPF, O. \& PFIFFNER, O. A. 2004. Early Tertiary evolution of the North Alpine Foreland Basin of the Swiss Alps and adjoining areas. Basin Research 16, 549-67.

LACOMBE, O. \& MOUTHEREAU, F. 2002. Basement-involved shortening and deep detachment tectonics in foreland orogens: Insights from recent collision belts (Taiwan, Western Alps, Pyrenees). Tectonics 21(4), doi: 10.1029/2001TC901018.

Löw, S. 1987. Die Tektono-Metamorphe Entwicklung der Nördlichen Adula-Decke (Zentralalpen, Schweiz). Beiträge zur geologischen Karte der Schweiz, Neue Folge 161, 84 pp.

MANCKTELOW, N. 2008. Tectonic pressure: theoretical concepts and modelled examples. Lithos 103, 149-77.

ManzotTi, P., Ballèvre, M., ZuCali, M., Robyr, M. \& ENGI, M. 2014. The tectonometamorphic evolution of the Sesia-Dent Blanche nappes (internal Western Alps): review and synthesis. Swiss Journal of Geosciences 107, 309-36.

Markley, M. J., Teyssier, C. \& CABy, R. 1999. Reexamining Argand's view of the Siviez-Mischabel nappe. Journal of Structural Geology 24, 1937-55.

Marquer, D., Baudin, T., Peucat, J.-J. \& Persoz, F. 1994. $\mathrm{Rb}-\mathrm{Sr}$ mica ages in the Alpine shear zones of the Truzzo granite: timing of the Tertiary alpine P-T-deformations in the Tambo nappe (Central Alps, Switzerland). Eclogae Geologicae Helvetiae 87, 225-39.

MAYERAT-DEMARNE, A.-M. 1994. Analyse Structurale de la Zone Frontale de la Nappe du Tambo (Pennique, Grisons, Suisse). Beiträge zur geologischen Karte der Schweiz, Neue Folge 165, 68 pp.

Milnes, A. G. \& SCHMUTZ, H.-U. 1978. Structure and history of the Suretta nappe (Pennine zone, Central Alps) - a field study. Eclogae Geologicae Helvetiae 71, 19-33.

Mohn, G., Manatschal, G., Masini, E. \& Müntener, O. 2011. Rift-related inheritance in orogens: a case study from the Austroalpine nappes in Central Alps (SESwitzerland and N-Italy). International Journal of Earth Sciences (Geologische Rundschau) 100, 927-61.

NÄNNY, P. 1948. Zur Geologie der Prätigauschiefer zwischen Rhätikon und Plessur. Mitteilungen des Geologis- chen Institutes der ETH und Universität Zürich C130, $127 \mathrm{pp}$.

NAGEL, T. J. 2008. Tertiary subduction, collision and exhumation recorded in the Adula nappe, central Alps. In Tectonic Aspects of the Alpine-DinarideCarpathian System (eds S. Siegesmund, B. Fügenschuh $\&$ N. Froitzheim), pp. 365-92. Geological Society of London, Special Publication no. 298.

Nagel, T. J., De Capitani, C., Frey, M., Froitzheim, N., STÜNITZ, H. \& SCHMID, S. M. 2002. Structural and metamorphic evolution during rapid exhumation in the Lepontine dome (southern Simano and Adula nappes, Central Alps, Switzerland). Eclogae Geologicae Helvetiae 95, 301-21.

Oberhänsli, R., Bousquet, R., Engi, M., Goffé, B., Gosso, G., Handy, M., HÖcK, V., Keller, F., Lardeaux, J.-M., Polino, R., Rossi, Ph., Schuster, R., Schwartz, S. \& Spalla, I. 2004. Metamorphic Structure of the Alps (Map 1:1,000,000). Paris: Commission for the Geological Map of the World, SGMW.

OBERHAUSER, R. 1998. Geologisch-Tektonische Übersichtskarte Vorarlberg 1:200,000 mit Erläuterungen. Wien: Geologische Bundesanstalt.

O'HARA, K. 2007. Reaction weakening and emplacement of crystalline thrusts: diffusion control on reaction rate and strain rate. Journal of Structural Geology 29, 1301-14.

Petrini, K. \& PodladchiKov, Y. 2000. Lithospheric pressure-depth relationships in compressive regions of thickened crust. Journal of Metamorphic Geology 18, $67-77$.

PFIFFNER, O. A. 1985. Displacements along thrust faults. Eclogae Geologicae Helvetiae 78, 313-33.

PFIFFNER, O. A. 1986. Evolution of the north Alpine foreland basin in the Central Alps. In Foreland Basins (eds P. A. Allen \& P. Homewood), pp. 219-28. Special Publication of the International Association of Sedimentologists no. 298.

PFIFFNER, O. A. 1993. The structure of the Helvetic nappes and its relation to the mechanical stratigraphy. Journal of Structural Geology 15, 511-21.

PFIFFNER, O. A. 2006. Thick-skinned and thin-skinned styles of continental contraction. In Styles of Continental Contraction (eds S. Mazzoli \& R. W. H. Butler), pp, 153-77. Geological Society of America, Special Papers 414.

PfiffNer, O. A. 2011. Structural Map of the Helvetic Zone of the Swiss Alps including Vorarlberg (Austria) and Haute Savoie (France) 1:100,000. Geological Special Map No. 128, Explanatory notes. Swiss Geological Survey/swisstopo, $128 \mathrm{pp}$., $10 \mathrm{pl}$.

PFIFFner, O. A. 2014. Geology of the Alps. Chichester: Wiley-Blackwell, $376 \mathrm{pp}$.

Pfiffner, O. A., Burkhard, M., HänNI, R., KAMMER, A., Kligfield, R., MANCKTElOW, N., MENKVELD, J.-W., RAMSAY, J. G. SCHMID, S. M. \& ZURBRIGGEN, R. 2010. Structural Map of the Helvetic Zone of the Swiss Alps including Vorarlberg (Austria) and Haute Savoie (France) 1:100,000. Geological Special Map No. 128. Swiss Geological Survey/swisstopo, 7 map sheets.

Pfiffner, O. A. \& Deichmann, N. 2014. Seismotektonik der Zentralschweiz. Nagra Arbeitsbericht NAB 14-26. Wettingen: Nationale Genossenschaft für die Lagerung radioaktiver Abfälle.

PFIFFNER, O. A. \& HiTZ, L. 1997. Geologic interpretation of the seismic profiles of the Eastern Traverse (lines E1 E3, E7 - E9): eastern Swiss Alps. In Deep Structure of the Swiss Alps: Results of NRP 20 (eds O. A. Pfiffner, P. Lehner, P. Heitzmann, S. Mueller \& A. Steck), pp. 73-100. Basel: Birkhäuser Verlag. 
PfiffNeR, O. A. \& RAMSAY, J. G. 1982. Constraints on geological strain rates: arguments from finite strain states of naturally deformed rocks. Journal of Geophysical Research 87(B1), 311-21.

Pfiffner, O. A., SAhli, S. \& StäUble, M. 1997. Structure and evolution of the external basement massifs (Aar, Aiguilles Rouges/Mt. Blanc). In Deep Structure of the Swiss Alps: Results of NRP 20 (eds O. A. Pfiffner, P. Lehner, P. Heitzmann, S. Mueller \& A. Steck), pp. 139-53. Basel: Birkhäuser Verlag.

Pleuger, J. \& PodladChIKOV, Y. Y. 2014. A purely structural restoration of the NFP20-East cross section and potential tectonic overpressure in the Adula nappe (central Alps). Tectonics 33, 565-685.

Probst, PH. 1980. Die Bündnerschiefer des Nördlichen Penninikums Zwischen Valser Tal und Passo die San Giacomo. Beiträge geologische Karte Schweiz Neue Folge $153,63 \mathrm{pp}$.

RODGERS, J. 1949. Evolution of thought on structure of middle and southern Appalachians. American Association of Petroleum Geologists Bulletin 33, 1643-54.

Rosenbaum, G. \& Lister, G. S. 2005. The Western Alps from the Jurassic to Oligocene: spatio-temporal constraints and evolutionary reconstructions. Earth-Science Reviews 69, 281-306.

RosenberG, C. L. \& Kissling, E. 2013. Three-dimensional insight into Central-Alpine collision: lower-plate or upper-plate indentation. Geology 41, 1219-22.

ROYSE, F. 1993. An overview of the geologic structure of the thrust belt in Wyoming, northern Utah, and eastern Idaho. In Geology of Wyoming (eds A. W. Snoke, J. R. Steidtmann \& S. M. Roberts), pp. 272-311. Geological Survey of Wyoming Memoir 5.

SARTORI, M. 1987. Structure de la zone du Combin entre les Diablons et Zermatt (Valais). Eclogae Geologicae Helvetiae 80, 789-814.

SARTORI, M., GOUFFON, Y. \& MARTHALER, M. 2006. Harmonisation et définition des unites lithostratigraphiques briançonnaises dans les nappes penniques du Valais. Eclogae Geologicae Helvetiae 99, 363-407.

SCHEIBER, T., Pfiffner, O. A. \& SChreurs, G. 2012. Strain accumulation during basal accretion in continental collision - a case study from the Suretta nappe (eastern Swiss Alps). Tectonophysics 579, 56-73.

Scheiber, T., PFiffNer, O. A. \& SChreURS, G. 2013. Upper crustal deformation in continent-continent collision: a case study from the Bernard nappe complex (Valais, Switzerland). Tectonics 32, 1320-42.

ScHMID, S. M. 1973. Geologie des Umbrailgebiets. Eclogae Geologicae Helvetiae 66, 101-210.

SCHMID, S. M. \& HAAS, R. 1989. Transition from nearsurface thrusting to intrabasement decollement, Schlinig thrust, Eastern Alps. Tectonics 8, 697-718.

SCHMID, S. M. \& KISSLING, E. 2000. The arc of the Western Alps in the light of geophysical data on deep crustal structure. Tectonics 19, 62-85.

SCHMID, S. M., PfiffNer, O. A., FroitzheIM, N., SCHÖNBORN, G. \& KISSLING, E. 1996. Geophysicalgeological transect and tectonic evolution of the SwissItalian Alps. Tectonics 15, 1036-64.

Schmid, S. M., Pfiffner, O. A. \& Schreurs, G. 1997. Rifting and collision in the Penninic zone of eastern Switzerland. In Deep Structure of the Swiss Alps: Results of NRP 20 (eds O. A. Pfiffner, P. Lehner, P. Heitzmann, S. Mueller \& A. Steck), pp. 160-85. Basel: Birkhäuser Verlag.

Schmid, S. M., RÜCK, PH. \& Schreurs, G. 1990. The significance of the Schams nappes for the reconstruc- tion of the palaeotectonic and orogenic evolution of the Penninic zone along the NFP-20 East traverse (Grisons, eastern Switzerland). In Deep Structure of the Alps (eds F. Roure, P. Heitzmann \& R. Polino), pp. 263-87. Mémoire de la Société Géologique de France 156.

SCHREURS, G. 1995. Geometry and Kinematics of the Schams Nappes and Adjacent Tectonic Units in the Penninic Zone, The Schams Nappes (Part II). Beiträge zur geologischen Karte der Schweiz, Neue Folge 167, $111 \mathrm{pp}$.

SCHUMACHER, M. 1997. Geological interpretation of the seismic profiles through the Southern Alps (lines S1-S7 and C3-south). In Deep Structure of the Swiss Alps: Results of NRP 20 (eds O. A. Pfiffner, P. Lehner, P. Heitzmann, S. Mueller \& A. Steck), pp. 101-14. Basel: Birkhäuser Verlag.

Selzer, C., Buiter, S. J. H. \& Pfiffner, O. A. 2008. Numerical modeling of frontal and basal accretion at collisional margins. Tectonics 27, TC3001, doi: 10.1029/2007TC002169.

STAMPFLI, G. M. 1993. Le Briançonnais, terrain exotique dans les Alpes? Eclogae Geologicae Helvetiae 86, $1-45$.

Smithson, S. B., Brewer, J., Kaufman, S., Oliver, J. \& HURICH, C. 1978. Nature of the Wind River thrust, Wyoming, from COCORP deep-reflection data and from gravity data. Geology 6, 648-52.

Steck, A., Della Torre, F., Keller, F., Pfeifer, H.-R., HUNZIKER, J. \& MASSON, H. 2013. Tectonics of the Lepontine Alps: ductile thrusting and folding in the deepest tectonic levels of the Central Alps. Swiss Journal of Geosciences 106, 427-50.

StecK, A., MAsson, H. \& RoBYR, M. 2015. Tectonics of the Monte Rosa and surrounding nappes (Switzerland and Italy): tertiary phases of subduction, thrusting and folding in the Pennine Alps. Swiss Journal of Geosciences 108, 3-34.

SteINMANN, M. 1994. Ein Beckenmodell für das Nordpenninikum der Ostschweiz. Jahrbuch der Geologischen Bundesanstalt 137, 675-721.

SteinmanN, M. \& Stille, P. 1999. Geochemical evidence for the nature of the crust beneath the North Penninic basin oft he Mesozoic Tethys Ocean. Geologische Rundschau 87, 633-43.

SuPPE, J. 1984. Principles of Structural Geology. New Jersey: Prentice-Hall.

SuPPE, J. 2014. Fluid overpressures and the strength of the sedimentary upper crust. Journal of Structural Geology 69, 481-92.

TEYSSIER, C. 1985. A crustal thrust system in an intracratonic tectonic environment. Tectonophysics 7, 689-700.

TROMMSDORFF, V. 1990. Metamorphism and tectonics in the Central Alps: the Alpine lithospheric mélange of Cima Lunga and Adula. Società Geologica Italiana, Memorie 45, 39-49.

TRÜMPY, R. 1969. Die helvetischen Decken der Ostschweiz: versuch einer palinspastischen korrelation und ansätze zu einer kinematischen analyse. Eclogae Geologicae Helvetiae 62, 105-42.

VON BLANCKENBURG, F. \& DAVIS, J. H. 1995. Slab breakoff: a model for syncollisional magmatism and tectonics in the Alps. Tectonics 14, 120-31.

Wagner, M., Kissling, E. \& Husen, S. 2012. Combining controlled-source seismology and local earthquake tomography to derive a 3-D crustal model of the western Alpine region. Geophysical Journal International 191, 789-802. 
WiederKeHR, M., Bousquet, R., Schmid, S. M. \& BERGER, A. 2008. From subduction to collision: thermal overprint of HP/LT meta-sediments in the north-eastern Lepontine Dome (Swiss Alps) and consequences regarding the tectono-metamorphic evolution of the Alpine orogenic wedge. Swiss Journal of Geosciences 101(Supplement 1), 127-55.

Yeck, W. L., Sheehan, A. F., Anderson, M. L., Erslev, E. A., Miller, K. C. \& SidDoway, C. S. 2014.
Structure of the Bighorn Mountain region, Wyoming, from teleseismic receiver function analysis: implications for the kinematics of Laramide shortening. Journal of Geophysical Research: Solid Earth 119, 7028-42.

YonkeE, A. \& WeIL, A. B. 2015. Tectonic evolution of the Sevier and Laramide belts within the North American Cordillera orogenic system. Earth-Science Reviews 150, 531-93. 